\title{
STOGODIŠNJA KONTROVERZA O SUODGOVORNOSTI SRBIJE ZA SARAJEVSKI ATENTAT I PRVI SVJETSKI RAT (1915. - 2015.)
}

Tihomir RAJČIĆ

OŠ kneza Mislava, Kaštel Sućurac Split, Hrvatska
UDK: 94(497.6 Sarajevo)“1914“"

DOI: $10.21857 / \mathrm{mnlqgc} 5 \mathrm{~d} 5 \mathrm{y}$

Pregledni rad

Prihvaćeno: 9. ožujka 2020.

Autor se u ovom članku bavi historiografskim kontroverzama o suodgovornosti Kraljevine Srbije za Sarajevski atentat i Prvi svjetski rat. Polazeći od pretpostavke američko-francuskog povjesničarskog dvojca Jaya Wintera i Antoniea Prosta da sve države i svi narodi, u različitoj mjeri, dijele odgovornost za izbijanje rata, autor donosi opširan pregled pitanja suodgovornosti Kraljevine Srbije koji obuhvaća 65 historiografskih, politoloških i memoarskih naslova, uglavnom nedostupnih u Hrvatskoj, objavljenih u razdoblju od 1915. do 2015. Ovaj pregled predstavlja uvod u detaljnije istraživanje zanimljivog pitanja o suodgovornosti Kraljevine Srbije za Prvi svjetski rat koje je, kroz ideologiju i politiku jugoslavenstva, u znatnoj mjeri obilježilo sudbinu Hrvatske u XX. stoljeću.

Ključne riječi: suodgovornost Srbije, historiografska kontroverza, Prvi svjetski rat.

Postoji „uska povezanost između političkih obzira nekog društva i njegovih interpretacija povijesti“, zbog čega „povijesne kontroverze treba proučavati u kontekstu aktualnih političkih preokupacija“, napisala je 2002. britanskonjemačka povjesničarka Anika Mombauer osvrćući se na kontroverze o uzrocima Prvog svjetskog rata. ${ }^{1}$ Ove riječi vjeran su opis pozadine stogodišnje kontroverze o suodgovornosti Kraljevine Srbije za Sarajevski atentat i Prvi svjetski rat koja uključuje različita strateška, politička i svjetonazorska stajališta o Srbiji, i kasnije Jugoslaviji, koja su nerijetko potkrijepljena kontradiktornim i nedorečenim povijesnim svjedočanstvima.

Zbog toga stalno pred očima valja imati stajališta koja je 2005. iznio američko-francuski povjesničarski dvojac Jay Winter i Antonie Prost kako „sve države, svi narodi, u različitoj mjeri dijele odgovornost za katastrofu koju nisu bili u stanju predvidjeti i spriječiti“. ${ }^{2}$ To znači da pitanje suodgovornosti Kraljevine Srbije za Sarajevski atentat i Prvi svjetski rat ima puno kompleksniju pozadinu koja se ne može svesti na upiranje prstom u službeni Beograd, ni na negiranje njegove suodgovornosti.

Anika Mombauer, The Origins of the First world War, London, 2002., 222.

Jay Winter and Antonie Prost, The Great War in History, Cambridge, 2005., 56, 204. 
$\mathrm{U}$ tom smislu ovaj članak nastavak je mog istraživanja problema razine suodgovornosti Kraljevine Srbije za izbijanje Prvog svjetskog rata započetog još 2014. Ovo je istraživanje osim prigodnih publicističkih kolumni u Slobodnoj Dalmaciji kojima svake godine javno ističem nedovoljno poznatu beogradsku pozadinu Sarajevskog atentata, ${ }^{3}$ rezultiralo člankom „Problem uloge Kraljevine Srbije u Sarajevskom atentatu i izbijanju Prvog svjetskog rata“, koji je 2017. objavljen u Radovima Zavoda za povijesne znanosti HAZU u Zadru. ${ }^{4}$

Sažimajući dotadašnje rezultate svog istraživanja, koje je zbog obilja srbijanskih, općenito europskih, a posebno britanskih dokumenata, u ovom trenutku kreće logičnim putem pisanja monografije, u zaključku članka sam konstatirao: „Zato na kraju valja ustvrditi da se razina odgovornosti Kraljevine Srbije za Sarajevski atentat i izbijanje Prvog svjetskog rata ogleda ponajprije u postajanju terorističko-obavještajne mreže čiji su konci sezali od službenog Beograda, preko Drine u Bosnu i Hercegovinu. Djelatnici ove mreže u najmanju su ruku bili suorganizatori Sarajevskog atentata za koji su Nikola Pašić i njegovi suradnici znali vjerojatno već početkom 1914., a u najmanju ruku od kraja svibnja 1914., ali nisu, zbog političkih i ideoloških razloga, učinili ništa da ga spriječe. Stoga im nakon atentata nije preostalo ništa drugo nego zataškavati i negirati svoj dio odgovornosti za krizu koja je uslijedila." ${ }^{\text {"5 }}$

Kad se zna ovo, ne treba čuditi što je tijekom stoljetnog razdoblja o kojem je ovdje riječ vođena, u hrvatskoj historiografiji gotovo sasvim nepoznata rasprava o odgovornosti, pa čak i o krivnji Kraljevine Srbije za izbijanje Prvog svjetskog rata. U tom je smislu posebno zanimljiva skoro polustoljetna rasprava o krivnji Srbije koju je, u kontekstu polemičkih rasprava o krivnji Njemačke, AustroUgarske, Rusije, Francuske i Velike Britanije, moguće pratiti u razdoblju od 1915. do 1961.

3 Mac Milan: Crna ruka je bila kao Al-Qa'd. Bataković: Nije istina Srbija je bila uzorna, Slobodna Dalmacija 30. lipnja 2014, https://slobodnadalmacija.hr/vijesti/svijet/macmillan-crna-ruka-jekao-al-qa-ida-batakovic-nije-istina-srbija-je-bila-uzorna-238534, posjećeno 23. 6. 2020.; Gdje je udarala Crna ruka? U toj četničkoj organizaciji bilo je i uglednih Splićana, Slobodna Dalmacija 15. veljače 2017. https://slobodnadalmacija.hr/vijesti/hrvatska/gdje-je-udarala-crna-ruka-utoj-cetnickoj-organizaciji-bilo-je-i-uglednih-splicana-468548, posjećeno 23. 6. 2020.; Atentat na Franju Ferdinanda dio je projekta Velike Srbije, Slobodna Dalmacija, 30. lipnja 2018.; Beogradski plan: Kad propadne Austrija, nastat će Velika Srbija, Slobodna Dalmacija, 6. srpnja 2019.; Tihomir RAJČıć, Ferdinanda je u smrt odveo njegov general, Slobodna Dalmacija, 28. lipnja 2020.

4 Tihomir Rajčıć, Problem uloge Kraljevine Srbije u Sarajevskom atentatu i izbijanju Prvog svjetskog rata, Radovi Zavoda za povijesne znanosti HAZU u Zadru, 59, Zagreb-Zadar, 2017., 407 $-434$.

5 T. Rajčıć, Problem uloge Kraljevine Srbije u Sarajevskom atentatu i izbijanju Prvog svjetskog rata, 434 . 


\section{RASPRAVE O KRIVNJI SRBIJE (1915. - 1961.)}

Američki politolog sa Sveučilišta Columbia John William Burgess ${ }^{6}$ koji je već u travnju 1915., dakle samo osam mjeseci nakon izbijanja Prvog svjetskog rata, u svojoj knjizi The European War of 1914 veliki dio krivice za izbijanje rata svalio je na Srbiju koju je smatrao „neobuzdanom zajednicom“ („turbulent community“) i koju, zbog toga što joj je pripisivao nedostatak civilizirane društvene moralnosti, nije htio nazvati državom. Vjerojatno se oslanjajući na knjižicu koju je 1915. objavio austrougarski konzulat u New Yorku, Burgess je organizaciju Sarajevskog atentata pogrešno pripisao samo „Narodnoj odbrani“ što znači da, vjerojatno, nije imao uvid u zapletenu političku i obavještajnu situaciju u tadašnjoj Srbiji u kojoj je važnu ulogu igrala „Crna ruka“ i njezin stvarni vođa Dragutin Dimitrijević Apis. U skladu s tim Burgess je smatrao da su dužnosnici Beogradske vlade 1914. sudjelovali u ,žalosnom kriminalnom aktu“ koji je nastavak djelatnosti „pobunjenika, zavjerenika i kraljoubojica“ koji su još od 1908. ugrožavali Austro-Ugarsku, iza čega on vidi antinjemačke strateške ciljeve Velike Britanije, Francuske i Rusije. U pozadini ovih stajališta svakako valja imati na umu da je Burgess bio nesuđeni savjetnik austrougarskog prijestolonasljednika Franje Ferdinanda za federalno preuređenje Austro-Ugarske koju je smatrao najzanimljivijim civilizacijskim i demokratskim eksperimentom XX. stoljeća. ${ }^{7}$

Nasuprot Bugressu, britanski liberalni parlamentarac Noel Buxton ${ }^{8}$ i njegov brat, laburistički parlamentarac Charles Roden Buxton ${ }^{9} \mathrm{u}$ knjizi The War and The Balkans, također objavljenoj u travnju 1915., negirali su krivnju Srbije za rat. Promatrajući Srbiju kao korisnog britanskog ratnog saveznika, autori smatraju da su Balkan i Srbija bili tek povod za rat čiji su glavni uzrok „duboko neprijateljstvo

6 John W. Burgess (1844. - 1931.) bio je američki povjesničar, politički teoretičar i stručnjak za ustavno pravo. Kao obrazovani germanofil bio je potresen činjenicom što su najprije Velika Britanija, a zatim i SAD ratovale protiv Njemačke. https://www.anb.org/view/10.1093/ anb/9780198606697.001.0001/anb-9780198606697-e-1400087, posjećeno 24. 5. 2020.; Sidney B. FAY, The Origins of the World War, vol II., New York 1928., 22.

7 John William BuRgess, The European War of 1914. It's causes, purposes, and probable results, Chicago, 1915., 5, 8, 9, 11, 17-27, 29-33, 162; Albert APPONYI, Austria-Hungary and War, New York, 1915.; S. B. FAY, The Origins of the World War, vol II., 22.

8 Noel Buxton (1869. - 1948.) bio je britanski liberalni parlamentarac s povjesničarskim obrazovanjem stečenim na Sveučilištu Cambridge. Zalagao se za ulazak Velike Britanije u Prvi svjetski rat, ali i za, usporedno, diplomatsko rješenje sukoba. https://spartacus-educational.com/TUbuxtonN.htm, posjećeno 24. 5. 2020.

9 Charles R. Buxton (1875. - 1942.) bio je britanski liberalni i laburistički političar obrazovan na Sveučilištu u Cambridge. Prije Prvog svjetskog rata bio je u neslužbenoj diplomatskoj misiji na Balkanu. http://www.bodley.ox.ac.uk/dept/scwmss/wmss/online/blcas/buxton-cr.html, posjećeno 24. 5. 2020. 
između velikih sila“. Ipak, autori uočavaju da je Srbija za Austro-Ugarsku prije rata bila „opasna mala država“ koja je, kao i ostale balkanske države, bila središte ne samo balkanskog iredentizma nego i balkanskog kolonijalizma. U tom smislu, s obzirom da su Srbiju vidjeli kao središte okupljanja „snažne i odlučne nacije“, koju nazivaju srpsko-hrvatskom ili jugoslavenskom, autori smatraju da je službeni Beč Sarajevski atentat pripisao „srbijanskim intrigama“ koje su bile povod za „uvredljivi ultimatum“ koji Srbija nije mogla prihvatiti i koji je u rat uvukao Rusiju. ${ }^{10}$

Otprilike $u$ isto vrijeme odgovornost službenog Beograda negirao je i francuski ekonomist Yves Gyot ${ }^{11}$ u svojoj knjizi o uzrocima i mogućim posljedicama rata. Naime, iako Sarajevski atentat smatra zločinom, Gyot u njegovoj pozadini vidi otpor agresivnim namjerama Austro-Ugarske koja je, zbog straha od jačanja pokreta srpsko-hrvatskog jedinstva na svom teritoriju, htjela uništiti Srbiju, u čemu je imala potporu militarističke Njemačke. ${ }^{12}$

Krivnju Srbije negirao je i bivši njemački veleposlanik u Londonu Karl Max von Lichnowsky ${ }^{13}$ u pamfletu My Mission to London objavljenom 1918. bez autorove privole, koji se temeljio na njegovu povjerljivom memorandumu iz 1916. Promatrajući situaciju iz pozicije veleposlanika čiji je zadatak bio osigurati neutralnost Velike Britanije, Lichnowsky ističe kako je u Londonu nakon Sarajevskog atentata počelo prevladavati mišljenje da Austro-Ugarska nastoji zloupotrijebiti smrt Franje Ferdinanda da bi opravdala napad na Srbiju, zbog čega je austrougarski ultimatum od 23. srpnja 1914. dočekan s nepovjerenjem. On zato pogrešnom smatra njemačku potporu Austro-Ugarskoj danu početkom srpnja 1914. jer je time ohrabrena pretjerana agresivnost Beča koji je zanemario upozorenja Rusije, ali i popustljivost Srbije koja je prihvatila gotovo čitavi ultimatum, osim dviju točaka, o kojima se moglo pregovarati. Zbog toga, ali i zbog njemačkog držanja krajem srpnja 1914., Lichnowsky smatra da „nije

10 Noel Buxton, Charles R. Buxton, The War and The Balkans, London, 1915., 9, 10, 15, 36, 37, $41-48$,

11 Yves Gyot (1843. - 1928) bio je utjecajni francuski liberalni ekonomist. https://oll.libertyfund.org/ people/yves-guyot, posjećeno 24. 5. 2020.; Charles Gide, Yves Guyot (1843-1928), The Economic Journal, Volume 38, Issue 150, 1 June, 1928., 332 - 334.

12 Yves Guyot, Causes and Cosenquences of the War, London, 1916., X, 3, 7, 18 - 20, 270 - 272. Francuski izvornik objavljen je u Parizu 1915. pod naslovom Les Causes et les Consénqences de la Guerre.

13 Karl M. von Lichnowsky, (1860. - 1928.) bio je njemački diplomat. Kao poslanik u Londonu bio je svjedok povijesti koji je u napetim danima u srpnju 1914. nastojao spriječiti rat između Njemačke i Velike Britanije. Zbog uvjerenja da njemački politički i vojni vrh snosi odgovornost za izbijanje rata postao je politički emigrant. A. MomBAUER, The Origins of the First world War, 16, 17, 28 - 30; http://www.worldwar1.com/bioclic.htm, posjećeno 30. 5. 2020. 
čudno što čitav civilizirani svijet potpunu odgovornost za svjetski rat stavlja na naša leđa“. Vrlo je zanimljivo što Lichnowsky ističe da je Njemačka u doba Balkanskih ratova trebala zadovoljiti težnju Srbije da na albanskoj obali dobije izlaz na Jadran, jer je to za nju bilo pitanje preživljavanja, te da je savez s AustroUgarskom za Njemačku bio beskoristan jer je otuđio balkanske države koje su mogle biti njemačko tržište. Zato, stavljajući odgovornost za izbijanje rata pred vrata službenog Beča, Lichnowsky tvrdi da je Austro-Ugarska još od 1913. pripremala vojnu ekspediciju protiv Srbije, pri čemu je austrougarsko isticanje opasnosti od „velikosrpskog pokreta“ smatrao diplomatskom smicalicom, a ne realnom opasnošću. ${ }^{14}$

Ova stajališta Lichnowsky je opširnije razradio deset godina kasnije u knjizi Headaing for the Abyss, koja sadrži i njegovu vrlo zanimljivu diplomatsku prepisku. U ovoj knjizi Lichnowsky je ustvrdio kako je Sarajevski atentat trebalo promatrati kao problem krivičnog prava, a ne kao političko pitanje koje je službeni Beč iskoristio za opravdanje rata protiv Srbije. Zato je odgovornost ponovo svalio na Austro-Ugarsku jer je, gledajući s političkog stajališta, njezin napad na Srbiju, s ciljem da suzbije jugoslavenski pokret, izazvao svjetski rat. ${ }^{15}$

Nasuprot Lichnowskom, kontroverzni srbijanski diplomat u Berlinu Miloš Bogičević ${ }^{16}$ je knjižici osobnih sjećanja i diplomatskih zapažanja iz 1919. veliki dio krivnje za rat svalio na Srbiju za koju tvrdi da je vodila agresivnu vanjsku politiku s osloncem na Rusiju. Uz to, Bogićević tvrdi da je zbog unutrašnjeg sukoba civilnih i vojnih vlasti oko zasluga za pobjedu u Balkanskim ratovima beogradska vlada u prvoj polovici 1914., da bi izbjegla njihov pritisak u zemlji, komitskim (četničkim) gerilcima dala slobodne ruke za djelovanje u inozemstvu. Zato, smatra Bogićević, ni površni promatrač situacije u tadašnjoj Srbiji nije mogao „vjerovati da vlada nije znala ništa zavjereničkoj djelatnosti određenih krugova časnika, profesora i komita u Bosni“ i da ništa nije znala o pripremama „za Sarajevski atentat koje su se odvijale u Srbiji“. Analizirajući situaciju nakon atentata, Bogićević ističe kako je nezainteresiranost beogradske vlade za mjere koje je Austro-Ugarska namjeravala poduzeti, skupa s vrlo

14 Prince Lichnows ky, My Mission to London, New York, 1918., 6, 7, 9, 10 - 13, 31 - 37, 40, 41.

15 Prince LIChnows KY, Heading for the Abyss. Reminiscences, New York, 1928., XVIII, XXI - XXII, XXV, 10, 11, 20, 21, $375-378$.

16 M. Bogićević (1876. - 1938.) bio je srbijanski diplomat u Berlinu koji je nakon Prvog svjetskog rata ostao u Njemačkoj i sustavno dokazivao odgovornost Srbije za rat. Rezultat su bile zanimljive knjige čija kontroverza traje i danas. Opširnije u: Kontroverzni život, publicističko i političko djelovanje pravnika i diplomate Miloša Bogićevića, http://www.republika.co.rs/574-575/12.html, posjećeno 24. 5. 2020. 
samouvjerenim držanjem srbijanske diplomacije i srbijanskog tiska, ukazivala da je Srbija tada dobila jamstvo Rusije da je neće napustiti u slučaju sukoba s Austro-Ugarskom. ${ }^{17}$

Poznati austrijski povjesničar Alfred Francis Pribram $^{18}$ u svojoj knjizi Austrian Foreign Policy objavljenoj 1923., odbijajući raspravljati o pitanju krivnje za rat, ističe kako je ubojstvo Franje Ferdinanda u Beču „potvrdilo uvjerenje o neophodnosti obračuna sa Srbijom“iako je u izvješću Friedricha von Wiesnera, kojeg je Ministarstvo vanjskih poslova poslalo u Sarajevo da tamo provede istragu, pokazalo „da nije moguće utvrditi izravnu vezu između ubojstva i srpske vlade“. Unatoč tomu, ističe Pribram, službeni Beč vjerovao je da su vlada i dvor u Beogradu dugo podupirali velikosrpski pokret, zbog čega je Srbiji 23. srpnja 1914. upućen neprihvatljivi ultimatum koji je trebao biti uvod u lokalni rat i slabljenje Srbije, podjelom dijela njezina teritorija između susjednih balkanskih država. ${ }^{19}$

Dvije godine poslije Pribrama, britanski publicist i poznavatelj južnoslavenskog pitanja i branitelj Srbije i Jugoslavije R. W. Seaton-Watson ${ }^{20} u$ svojoj knjizi o Sarajevskom atentatu i uzrocima Prvog svjetskog rata ističe kako nije vjerojatno da je u trenutku političke krize zbog koje je Srbija bila potpuno nespremna za rat, beogradska vlada podupirala potencijalno opasne terorističke akcije na tuđem teritoriju. Stoga on najveći dio krivnje za izbijanje rata pripisuje službenom Beču koji je 1908., 1912. i 1913. planirao rat protiv Srbije, zbog čega ubojstvo Franje Ferdinanda smatra vrhuncem južnoslavenskih revolucionarnih akcija protiv bečkog režima koje su izveli mladobosanski atentatori na vlastitu inicijativu, ali uz pomoć terorista iz „Crne ruke“, koja je u to vrijeme bila u sukobu $s$ beogradskom vladom. ${ }^{21}$

17 Miloš Boghitcévitch, Causes of the War, Amsterdam-Rotterdam, 1919., 63 - 66.

18 A.F. Pribram (1859. - 1942.) bio je austrijski povjesničar čija je povjestica austrougarske diplomacije bila utjecajna u Americi i Velikoj Britaniji. Objavio je i dva toma tajnih austrougarskih sporazuma. https://www.biographien.ac.at/oebl/oebl_P/Pribram_Alfred-Francis_1859_1942.xml, posjećeno 24. 5. 2020.

19 Alfred Francis Pribram, Austrian foreign policy, 1908-1918., London, 1923., 61, 62, $63,66$.

20 R. S. Watson (1879. - 1915.) bio je britanski povjesničar i publicist i poznavatelj nacionalnog pitanja u Austro-Ugarskoj, posebno tadašnjeg južnoslavenskog pitanja. Opširnije u: Hugh SEATONWatson, Robert William Seaton Watson i jugoslavensko pitanje, Časopis za suvremenu povijest, 2/1970., br. 2, 75 - 97; Stjepan Matković, Ivo Pilar i Robert W. Seaton Watson, Pilar, I/2006., br. 1., 21 - 46. Hrvatska enciklopedija, https://www.enciklopedija.hr/natuknica.aspx?id=55572., posjećeno 24. 5. 2020.

21 Robert W. Seaton-Watson, Sarajevo. A study in the origins of the Great War, London, 1925., 53, 129 - 132. Jugoslavensko izdanje ove knjige objavljeno je u Zagrebu 1926. pod naslovom: Sarajevo. Studija o uzrocima svetskog rata. 
Jedinom točkom moguće odgovornosti Srbije Watson smatra dvojbe oko toga je li beogradska vlada izvršila svoju dužnost i obavijestila Beč o tome da se sprema atentat, zbog čega je beogradska vlada možda odgovorna za „compounding a felony“, krivično djelo prikrivanja drugog krivičnog djela, čije eventualno dokazivanje ne bi upućivalo na izravnu odgovornost beogradske vlade za Sarajevski atentat. ${ }^{22}$

Nasuprot Watsonu, američki sociolog i „revizionistički“ povjesničar Harry E. Barnes ${ }^{23}$ u svojoj knjizi The Genesis of the World War iz 1927. tvrdi kako je dugo nakon rata prevladavalo pogrešno uvjerenje da je Srbija „nedužna mala zemlja" koja nije odgovorna za ubojstvo nadvojvode Franje Ferdinanda. Stoga on, dokazujući krivnju Srbije, ističe da je iza Sarajevskog atentata stajala „družina ubojica“ pod vodstvom pukovnika Dragutina Dimitrijevića Apisa koji je u svoje planove uvrstio trojicu mladobosanskih dragovoljaca. Za sve ovo, pretpostavlja Barnes, znao je predsjednik beogradske vlade Nikola Pašić za kojeg je radio Apisov povjerljivi čovjek Milan Ciganović, što otvara mogućnost da je srbijanski državni vrh od samog početka bio upućen u čitavu stvar. Iako bečkoj vladi zamjera što je probleme sa Srbijom nastojala najprije riješiti silom, a tek onda pregovorima, Barnes taj postupak pripisuje agresivnom duhu vremena, ali i nemaru Srbije da nakon Sarajevskog atentata provede istragu na svome tlu. Zbog toga Barnes odbacuje tvrdnje „srpskih apologista“ kako je tada bilo previše zavjera protiv Austro-Ugarske da bi se beogradska vlada mogla baviti samo time. ${ }^{24}$

Sažimajući svoje argumente o krivnji Srbije, ali i Austro-Ugarske, Barnes ističe da je „sigurno da su srpski zavjerenici planirali ubojstvo nadvojvode učiniti sredstvom strmoglavljivanja Europe u rat, dok su austrijski vojni i civilni dužnosnici bili odlučni isto djelo upotrijebiti za dugo odgađano kažnjavanje Srbije. Pitanje je samo koji je od ovih planova bio nečasniji i opasniji. ${ }^{\text {"2s }}$

Slično Barnesu, i drugi američki „revizionistički“povjesničar Sidney Bredshaw Fay, koji je u prvoj polovici XX. stoljeća slovio za istaknutog poznavatelja

23 Harry E. Barnes (1889. - 1968.) bio je američki povjesničarski erudit, među ostalim poznat kao revizionist koji je nakon opsežnog istraživanja dokumenata 1920-ih krivnju za Prvi svjetski rat prebacio na sile Antante. Justus E. Doenecke, Harry Elmer Barnes, The Wisconsin Magazine of History, Vol. 56, No. 4, Summer, 1973., 311 - 323; A. Mombauer, The Origins of the First World War, 86 - 88. https://mises.org/library/harry-elmer-barnes-rip, posjećeno 30. 5. 2020.

24 Harry E. BARnes, The Genesis of the World War, London,-New York, 1927., 80 - 85, 153 - 159, 166, $167,170,171,172$.

25 H. E. BARnes, The Genesis of the World War, 173, 174. 
njemačke povijesti, ${ }^{26} \mathrm{u}$ drugom tomu svoje utjecajne studije The Origins of the World War iz 1928. veliki dio krivnje za izbijanja rata pripisuje Srbiji. „Ubojstvo nadvojvode užeglo je materijal koji inače ne bi planuo na način koji je planuo“, ističe Fay, ukazujući na utjecaj Sarajevskog atentata na vrlo napetu diplomatsku i vojnu situaciju u tadašnjoj Europi zbog čega smatra da je „važno slijediti tragove zavjere koja je pokosila nadvojvodu i utvrditi odgovornost za djelo koje je imalo tako strašne i mučne posljedice za čitav svijet". ${ }^{27}$

U tom smislu on ističe da su se u Beogradu tada odvijale „mračne pripreme“ za atentat na Franju Ferdinanda u kojima su važnu ulogu igrali „Narodna odbrana“, "Crna ruka“ i Dragutin Dimitrijević Apis, a sve s ciljem stvaranja „slavnog jugoslavenskog kraljevstva“. Mlade sarajevske atentatore Fay smatra jugoslavenskim i srpsko-hrvatskim revolucionarima koji su 1912. uspostavili vezu s „Crnom rukom“i četničkim aktivistima u Srbiji gdje se među informiranim ljudima duže vrijeme znalo da su pojedinci u vrhu vlasti „imali udjela u zavjeri za ubojstvo Franje Ferdinanda“. Zbog toga je, smatra Fay, beogradska vlada o svemu „trebala smjesta obavijestiti austrougarske vlasti“, a ne pokušati „prikriti svaki trag... u nadi da austrougarska vlada neće biti ustrajna u otkrivanju njihove umiješanosti“. Ipak, Fay smatra „potpuno sigurnim“ da Nikola Pašić i njegova vlada nisu imali ništa s organizacijom atentata za koji su vjerojatno doznali tek kada su mladi atentatori već bili na putu za Sarajevo, zbog čega im pripisuje „kriminalni nemar“, odnosno zataškavanje pozadine zavjere u koju je bio umiješan čak i glavni stožer srpske vojske. ${ }^{28}$ Zbog svega ovoga Fay tvrdi „da su austrijske optužbe protiv Srbije 1914., potvrđene dokazima sa suđenja, u stvari prije umjerena nego pretjerana procjena odgovornosti Srbije“. ${ }^{29}$

Nasuprot Fayu, bivši ruski ministar vanjskih poslova Sergej Sazonov ${ }^{30} \mathrm{u}$ svojim memoarima, objavljenima 1928., odbacuje bilo kakvu dogovornost Srbije. On smatra da su Sarajevski atentat izveli „fanatični mladići“ čiji „zločin Srbiji nije donosio nikakvu dobrobit“ i čiju povezanost s Beogradom nije dokazala ni

Sidney B. Fay (1876. - 1967.) bio je američki povjesničar i poznavatelj europske povijesti. Poznat je po tome što je 1928., nakon iscrpnog istraživanja do tada nekorištenih izvora, doveo u pitanje široko rasprostranjeno uvjerenje o odgovornosti Njemačke za izazivanje Prvog svjetskog rata. https://www.britannica.com/biography/Sidney-Bradshaw-Fay, Posjećeno 30. 5. 2020.

27 Sidney Bradshaw FaY, The Origins of the World War, volume II, New York, 1928., 53.

28 Sidney Bradshaw FaY, The Origins of the World War, volume II, 53, 57, 60 - 64, 81, 82, 127 - 153.

29 S. B. FaY, The Origins of the World War, volume II, 57.

30 Sergej D. Sazonov (1860. - 1927.), ruski državnik i diplomat koji je bio ministar vanjskih poslova od 1910. do 1916. i koji je u kritičnim srpanjskim danima 1914. odlučio zaštititi Srbiju od Austro-Ugarske i uz pomoć Francuske suprotstaviti se Njemačkoj. https://www.britannica.com/ biography/Sergey-Dmitriyevich-Sazonov, posjećeno 30. 5. 2020. 
službena austrougarska istraga. Uz to, Sazonov ističe da je ubojica bio bosanski Srbin, dakle austrougarski podanik, zbog čega čak tvrdi da je bečka vlada trebala povući svoje opasne optužbe protiv Srbije. Najveći dio odgovornosti za izbijanje Prvog svjetskog rata Sazonov zato pripisuje agresivnoj i nepromišljenoj politici Austro-Ugarske, ali i Njemačke, koja je podržala ratoborno držanje Beča. ${ }^{31}$

Nasuprot Sazonovu, američki antirevizionistički povjesničar sa Sveučilišta u Chicagu Bernadotte E. Schmitt ${ }^{32}$ u prvom tomu svoje knjige The Coming of the War 1914., objavljenom 1930., ističe da je Srbija, iako je nakon Sarajevskog atentata činila sve da ne oteža spor s Austro-Ugarskom, „kriva za strašnu pogrešku jer nije odmah provela brzu istragu o okolnostima koje su, na njenom tlu, prethodile Sarajevskom atentatu“. Iako, gledano na duge staze, držanje Srbije nije smatrao toliko važnim jer je "Austro-Ugarska bila odlučna voditi rat", Schmitt ističe da bi Pašić ,ako je imao spoznaja o zavjeri, pametnije postupio da je informacije prenio austrougarskoj vladi na nedvosmislen način“, zbog čega mu zamjera „zanemarivanje dužnosti“ koje se „teško može opravdati“. Schmitt organizatorima Sarajevskog atentata smatra „Narodnu odbranu“, koja je bila povezana s beogradskom vladom i Radikalnom strankom premijera Pašića, te „Crnu ruku“kojaje, usprkos prevratničkim sklonostima, bila povezana s vrhovima vlasti u Beogradu. Cilj ovih organizacija bio je stvaranje Velike Srbije, odnosno Jugoslavije, na račun Austro-Ugarske. Stoga Schmitt opravdanom smatra optužbu iz austrougarskog ultimatuma od 23. srpnja 1914. kako je službena Srbija kriva što je na svom teritoriju tolerirala propagandu protiv Austro-Ugarske. Ipak, on ističe kako je postupanje Austro-Ugarske u srpnju 1914. izgledalo kao „korak koji će utjecati na samostalnost Srbije“, ali i poremetiti europsku ravnotežu sila. ${ }^{33}$

Nasuprot Schmittu, dr. Božo Čerović, koji je u doba Sarajevskog atentata bio savjetnik u zajedničkom austrougarskom ministarstvu financija u Beču, nadležnom za Bosnu i Hercegovinu, ${ }^{34}$ dakle svjedok povijesti, u svojim memoarima objavljenima 1930., koji su mješavina zapažanja obrazovanog

31 Serge Sazonov, Fateful Years, London, 1928., 150 - 152, 164 - 166.

32 Bernadotte E. Schmitt (1886. - 1969.) bio je profesor suvremene europske povijesti na Sveučilištu u Chicagu. Poznat je po tome što je 1920-ih ustvrdio kako Njemačka ne može biti jedini krivac za izbijanje Prvog svjetskog rata, nego da krivnja treba biti podijeljena među državama sudionicama tog sukoba. University of Chicago. Guide to the Bernadotte E. Schmitt Papers 1913-1961.

https://www.lib.uchicago.edu/e/scrc/findingaids/view.php? eadid=ICU.SPCL.SCHMITT\# idp76768840, posjećeno 30. 5. 2020.; Anika Mombauer, The Origins of the First World War, $101,102$.

33 Bernadotte E. Schmit, The Coming of the War 1914, volume I, New York-London, 1930.,175 - 219, 241, 445, 470, 471.

34 Leon BILIŃs KI, Bosna i Hercegovina u uspomenama Leona Bilińskog, 29. 
pojedinca i povijesnih izvora, u potpunosti odbacuje tvrdnje o odgovornosti službenog Beograda. Po njegovu mišljenju „neprijatelji Jugoslavije terete bivšu srpsku vladu za atentat" iako istraga posebnog činovnika bečkog Ministarstva vanjskih poslova Friedricha Wiesnera nije pružila nikakve dokaze za tu tvrdnju. Čerović, osim toga, smatra da su mladobosanci Sarajevski atentat od početka do kraja organizirali sami, mimo službenog Beograda, pri čemu im je pripadnik „Crne ruke" Vojislav Tankosić bio samo pomagač. ${ }^{35}$

Nasuprot Čeroviću, američki povjesničar Raymond J. Sontag ${ }^{36}$ u svojoj knjizi o povijesti europske diplomacije objavljenoj 1933. ističe da je Srbija prije Prvog svjetskog rata, ohrabrena od strane ruskog poslanika u Beogradu Nikolasa Hartwiga, na Austro-Ugarsku gledala kao na sljedeću žrtvu. U pozadini takvog držanja Sontag vidi „srbijansku vojnu kliku“ koja je bila previše moćna da bi je beogradska vlada mogla nadzirati i koja je "pod energičnim vodstvom pukovnika Dimitrijevića, časnika srbijanskog glavnog stožera, postala dovoljna jaka da je dominirala vojskom i utjecala na vladinu politiku", a sve s ciljem stvaranja velike južnoslavenske države pod vodstvom Srbije. Da bi ostvarila ovaj svoj cilj, smatra Sontag, ova je organizacija u Bosni i Hercegovini „poticala kult terorizma i revolucije koji je tamo već postojao" i čiji su izdanak bili mladi sarajevski atentatori. Oni su od agenata „Crne ruke“ dobili oružje iz srpskih vojnih arsenala i ,tako naoružani prokrijumčareni nazad u Bosnu i Hercegovinu preko tajnih linija komunikacija koje je društvo održavalo“.37

Vrlo je zanimljivo što Sontag ističe da je skoro sigurno da je srbijanski premijer Nikola Pašić imao saznanja o pripremama za Sarajevski atentat, ali da o svemu nije na odgovarajući način izvijestio vladu u Beču jer se bojao osvete „Crne ruke“. U tom smislu on austrougarski ultimatum Srbiji od 23. srpnja 1914. smatra „očajničkim potezom“, a beogradski odgovor na ultimatum samo prividno pomirljivim zbog čega je Beč odlučio primijeniti silu, riskirajući rat s Rusijom. U takvim okolnostima je, smatra Sontag, postupak Beča, zbog nedovršene sarajevske istrage, počeo izgledati kao agresivna i osvajačka politika, a ne traženje legitimne zadovoljštine za žrtve Sarajevskog atentata. ${ }^{38}$

35 Božo Čerović, Bosanska omladina i Sarajevski atentat, Sarajevo, 1930., 86 - 95.

36 Raymond J. Sontag (1897. - 1972.) bio je američki povjesničar europske diplomacije, savjetnik američke vlade i američke obavještajne službe CIA.

http://texts.cdlib.org/view?docId=hb9t1nb5rm\&doc.view=frames\&chunk.id=div00063\&toc. depth=1\&toc.id, posjećeno 30. 5. 2020.

37 Raymond J. Sontag, European Diplomatic History 1871- 1932., New York, 1933., 177, 191

38 R. J. Sontag, European Diplomatic History, 176 - 197. 
Talijanski novinar i povjesničar Luigi Albertini ${ }^{39}$ u svojoj je globalno poznatoj zbirci povijesnih svjedočanstava o uzrocima Prvog svjetskog rata pokušao razdvojiti pitanje uzroka rata od pitanja krivice pri čemu smatra da je beogradska vlada vrlo vjerojatno znala za pripreme za Sarajevski atentat, ali zbog političkih okolnosti u zemlji, odnosno zbog „prevlasti pan-srpskog pokreta“, nije napravila ništa da atentat spriječi. Ispitujući ovaj problem na osnovi raspoloživih spoznaja i opširnih razgovora s mnogim svjedocima povijesti, Albertini zaključuje kako je predsjednik beogradske vlade Nikola Pašić pragmatično stajao između "Crne ruke“ i službenog Beča, odnosno da se bojao da bi nasilje „Crne ruke“ moglo dati povod Austro-Ugarskoj da napadne Srbiju koja je bila nespremna za rat. U prilog tome, smatra Albertini, govori podatak da je Pašić upozorio zapovjednika glavnog stožera srpske vojske vojvodu Putnika da veze glavnog vojnog obavještajca Dragutina Dimitrijevića Apisa s bosanskim revolucionarima mogu imati katastrofalne posljedice za Srbiju. U tom je smislu vrlo zanimljivo Albertinijevo zapažanje da je za Srbiju bila sretna okolnost to što je AustroUgarska za Sarajevski atentat optužila „Narodnu odbranu“, a ne „Crnu ruku“ jer time nije postavljeno ključno pitanje o tome koliko je beogradska vlada znala o planovima „Crne ruke“ i što je poduzela da te planove spriječi ili na odgovarajući način izvijesti bečku vladu. ${ }^{40}$

Procjenjujući stupanj suodgovornosti Srbije, u kontekstu činjenice da su beogradski organizatori Sarajevskog atentata bili povezani s vrhovima vlasti, odnosno da je Nikola Pašić vrlo vjerojatno bio upućen u čitavu zavjeru koju je zbog političkih razloga morao zataškati, Albertini postavlja pitanje „je li moralno i politički važnije pravo Austrije da brani svoj opstanak“ ili je važnije bilo pravo Srbije „da oslobodi svoju braću“ od austrougarske vlasti. ${ }^{41}$

Donekle slično Albertiniju, američki povjesničar Joachim $\operatorname{Remak}^{42} \mathrm{u}$ svojoj knjizi Sarajevo. Story of Political Murder iz 1959. tvrdi da Srbija ima „ogroman

39 Luigi Albertini (1871. - 1941.) bio je talijanski novinar, urednik uglednog dnevnika Coriere della Serre. Njegova trotomna studija o uzrocima Prvog svjetskog rata i danas je vrlo cijenjen historiografski rad, ali i relevantna zbirka povijesnih izvora. https://www.britannica.com/ biography/Luigi-Albertini. Posjećeno 30. 5. 2020.; A. Mombauer, The Origins of the First World War, 125, 126.

40 Luigi Albertini, The Origins of the War of 1914., volume II., Westport, Connecticut, 1980., Reprint, 89 - 109. Izvornik je objavljen u Milanu 1942. i 1943. pod naslovom Le origini della guerra del 1914.

41 Luigi Albertini, The Origins of the War of 1914., volume II., 273, 282, 283, 360, 372.

42 Joachim Remak (1920. - 2001.), američki stručnjak za europsku i njemačku povijest. Obrazovanje je stekao na Sveučilištu California, Berkeley i Sveučilištu Standford. Nakon ovdje korištene knjige Sarajevo. Story of Political Murder iz 1959. koja je nagrađena nagradom Instituta Hoover, napisao je brojne knjige i članke zbog kojih je stekao je ugled stručnjaka za uzroke Prvog svjetskog rata. https://senate.universityofcalifornia.edu/_files/inmemoriam/html/JoachimRemak.htm, posjećeno 31. 5. 2020. 
udio u izbijanju Prvog svjetskog rata“ jer „vlada u Beogradu nije poduzela nikakve mjere da spriječi atentat o kojem je imala prethodna saznanja“. Sam atentat, smatra Remak, isplanirala je „Crna ruka“, odnosno Dragutin Dimitrijević Apis, koji je, slično kao i predsjednik srbijanske vlade Nikola Pašić, bio nadahnut velikosrpski idealima. Zato je vrlo intrigantan Remakov zaključak kako bi međunarodni položaj Srbije bio sasvim drugačiji da je austrougarski ultimatum od 23. srpnja 1914. otvoreno ukazivao na djelatnost „Crne ruke“ i da je tražio uhićenje Dragutina Dimitrijevića Apisa, jer je više nego dvojbeno da bi Beograd dobio potporu saveznika i jer bi se Pašić našao u procjepu između vrlo riskantnog pokušaja uhićenja Apisa ili još opasnijeg odbijanja ultimatuma službenog Beča. ${ }^{43}$

Osam godina kasnije, Remak je u svojoj knjizi o uzrocima Prvog svjetskog rata ustvrdio da „razumjeti sve ne znači oprostiti sve“, odnosno opredijeliti se za perspektivu bilo koje od država sudionica „srpanjske krize“ 1914. Zato on, iako Austro-Ugarskoj i Srbiji pripisuje najveći stupanj odgovornosti za izbijanje rata, zaključuje kako je važno razumjeti interese, motive i okolnosti koje su utjecale na vodeće ljude u Beču, Beogradu, Sankt-Peterburgu, Berlinu i Londonu u trenutku kada su 1914. donosili sudbonosne odluke koje su rezultirale ratom. U tom smislu Remak smatra da je organizator Sarajevskog atentata najvjerojatnije bio Dragutin Dimitrijević-Apis, koji je krajem 1913. i početkom 1914. odlučio ukloniti austrougarskog prijestolonasljednika Franju Ferdinanda zbog njegovih zamisli o preuređenju Austro-Ugarske po američkom ili švicarskom federalnom modelu. Trojica budućih atentatora, koji su tada bili u Beogradu, trebali su Apisu poslužiti kao genijalna politička krinka koja će ovom planu dati obilježje izvornog bosanskog pothvata. Kada je Nikola Pašić, sredinom svibnja 1914., doznao za pripreme za atentat, svjestan rizika diplomatske krize s Bečom, ali i opasnost od novog udara „Crne ruke“ koju nije mogao sasvim nadzirati, odlučio je uputiti vrlo uvijeno i neodređeno upozorenje vlastima u Beču. ${ }^{44}$

Četiri godine kasnije Remak, u znanstvenom članku u kojem Prvi svjetski rat promatra kao Treći balkanski rat, ponovo ističe kako najveću odgovornost u čitavoj stvari snose Austro-Ugarska i Srbija. Odgovornost prve vidi u činjenici da je Beč puno prije Sarajevskog atentata želio izazvati mali balkanski rat protiv Srbije, dok službeni Beograd smatra odgovornim zbog toga što je „niz godina tolerirao, pa čak i poticao pokret za Veliku Srbiju čiji je cilj napad na AustroUgarsku“ i zbog toga što je glavni vojni obavještajac Dragutin Dimitrijević Apis planirao Sarajevski atentat. Zbog svega ovoga Remak smatra da „ogromni

43 Joachim Remak, Sarajevo. Story of Political Murder, New York, 1959., 71 - 77, 206, 207.

44 Joachim Remak, The Origins of World War I (1871.- 1914), New York, 1967., 97 - 101, 104, 105, $132-134$. 
udio odgovornosti Srbije“ proizlazi iz „zastrašujuće nebrige za posljedice“ velikosrpskih planova. ${ }^{45}$

Nasuprot Remaku, Drago Ljubibratić u biografijama sarajevskog atentatora Gavrila Principa i neslužbenog vođe i ideologa „Mlade Bosne“ Vladimira Gaćinovića ističe kako su Sarajevski atentat organizirali zaneseni mladobosanci uz diskretnu potporu „Crne ruke“, odnosno povjerljivih ljudi Dragutina Dimitrijevića Apisa, na prvom mjestu bojnika Vojislava Tankosića. Iako Ljubibratić smatra da beogradska vlada o svemu nije znala ništa sve do početka lipnja 1914., kad su mladi atentatori već bili prešli Drinu, on donosi obilje podataka o postojanju dobro organizirane beogradske obavještajne mreže koja je djelovala u Bosni i Hercegovini i koja je mladim atentatorima priskrbila znatnu novčanu potporu od 1000 dinara, otprilike 16 mjesečnih plaća učitelja početnika u tadašnjoj Srbiji. Pri tome, posebno je zanimljiva autorova pretpostavka da je jedan od članova vodstva „Crne ruke“, Radoje Lazić, bio povjerljivi čovjek Nikole Pašića, ${ }^{46}$ što bi moglo značiti da je Pašić bio upućen u pripreme za Sarajevski atentat koje su se u proljeće 1914. odvijale u Beogradu. U godini izdavanja Ljubibratićeve knjige o Vladimiru Gaćinoviću započela je tzv. „Fischerova kontroverza" koja je fokus istraživanja odgovornosti za izbijanje Prvog svjetskog rata skrenula prema Njemačkoj, zbog čega su rasprave suodgovornosti Srbije pale u drugi plan.

\section{NOVE SPOZNAJE U SJENI „FISCHEROVE KONTROVERZE“ 1961. -2000 .}

Utjecajni njemački povjesničar Fritz Fischer ${ }^{47}$ je 60 -ih godina prošlog stoljeća, koristeći nove arhivske podatke, dokazivao krivnju Njemačke za izazivanje Prvog svjetskog rata zbog čega je u svojoj poznatoj knjizi o njemačkim ratnim ciljevima, objavljenoj 1961., Srbiju spomenuo tek usput. Iz njegove perspektive Austro-Ugarska je još od Balkanskih ratova 1912. i 1913. Srbiju namjeravala u

45 Joachim Remak, The Third Balkan War. Origins reconsidered, The Journal of Modern History, vol. 43., no. 3, 1971., $361-364$.

46 Drago Ljubibratić, Gavrilo Princip, Beograd, 1959., 204 - 223, 289 - 292; D. Ljubibratić, Vladimir Gaćinović, Beograd, 1961., 100 - 103, 130 - 158; L. Aleksić-Pej Ković, Odnosi Srbije sa Francuskom i Engleskom, 185.

47 Fritz Fischer (1908. - 1999.), njemački povjesničar sa Sveučilišta u Hamburgu poznat je po svojoj tezi, utemeljenoj na prethodno nepoznatim dokumentima, da je vlada carske Njemačke, ciljajući ostvariti svjetsku moć, svjesno i namjerno izazvala Prvi svjetski rat. https://www.britannica.com/ biography/Fritz-Fischer.; https://www.open.edu/openlearn/history-the-arts/history/worldhistory/the-debate-on-the-origins-the-first-world-war, posjećeno 31. 5. 2019. 
potpunosti podrediti svojim interesima pa je Sarajevski atentat bio tek povod za ostvarivanje tog cilj. Ipak, nakon poznatog njemačkog „bjanko-čeka“ od 5. i 6. srpnja 1914. Austro-Ugarska nije organizirala brzu vojnu akciju, nego je 23. srpnja vladi u Beogradu uručila ultimatum koji je sastavljen s namjerom da bude neprihvatljiv i tako opravda vojnu intervenciju. ${ }^{48}$

U svojoj poznatoj knjizi War of illusions, German Policies from 1911 to 1914 Fischer ističe kako se u Berlinu vjerovalo da je situacija nakon Sarajevskog atentata bila povoljna za izazivanje svjetskog rata jer je ekspanzija Srbije 1912. i 1913. u Beču stvarala osjećaj straha od njezina budućeg utjecaja. Ipak, Fischer ističe kako je u Berlinu izgledalo da je ovaj balkanski problem moguće riješiti mirnim putem pa je car Willhelm II. bečkom vrhu čak savjetovao da Srbiju pridobije ekonomskim ustupcima i korumpiranjem vodstva zemlje od kralja nadolje. Štoviše, zbog strateških ekonomskih i političkih interesa, politika Berlina prije Prvog svjetskog rata bila je u određenoj mjeri čak i prosrpska. Ipak, nakon Sarajevskog atentata i „bjanko-čeka“ Njemačka je čvrsto stala iza namjere Beča da se obračuna sa Srbijom. ${ }^{49}$

Slično kao i Fischer, poznati srbijanski povjesničar i publicist Vladimir Dedijer $^{50}$ negira suodgovornost Srbije za Sarajevski atentat. Ipak, on u drugom tomu svoje knjige Sarajevo 1914., objavljenom 1978., donosi prilično detaljan pregled beogradske obavještajne mreže koja je djelovala u Bosni i Hercegovini, u čijoj su pozadini u proljeće 1914. bile napetosti između predsjednika beogradske vlade Nikole Pašića i „Crne ruke“. Dedijer pri tome ističe kako je u Beogradu tada postojala bojazan da će Austro-Ugarska razotkriti ovu obavještajnu mrežu koja je djelovala bez dogovora sa službenim vlastima, zbog čega je beogradska vlada imala vrlo ograničene spoznaje o Sarajevskom atentatu koji su organizirali „Crna ruka“ i „Mlada Bosna“. Dedijer smatra da je Pašić, čim je početkom lipnja 1914. dobio informacije o tome da se priprema atentat, naredio srbijanskim

48 A. Mombauer, The Origins of the First World War, 119 - 174; Fritz Fischer, Germany's war aims in the First World War, New York, 1967., 42 - 44, 52, 53, 55. Njemački izvornik objavljen je 1961. u Dortmundu pod naslovom Griff nach der Weltmacht. U Hrvatskoj je dostupan srpski prijevod koji nosi naslov Posezanje za svetskom moći: politika ratnih ciljeva carske Nemačke: 1914-1918., Beograd, 2014.

49 Fritz Fischer, War of illusions, German Policies from 1911 to 1914., New York, 1975., 218, 222, 260, 261, 291, 292, 410, 411, 473 - 488. Njemački izvornik objavljen je 1969. u Dortmundu pod naslovom Krieg der Illusionen.

50 Vladimir Dedijer (1914. - 1990.), srpski pravnik, povjesničar i publicist koji je uz razne političke dužnosti u Jugoslaviji predavao povijest u Beogradu, Stockholmu, Oslu, Kopenhagenu, Londonu, Harvardu, Princetonu, Columbiji, Los Angelesu. http://www.enciklopedija.hr/natuknica. aspx?id=14168; https://quod.lib.umich.edu/b/bhlead/umich-bhl-92119?rgn=main; view=text. Posjećeno 31. 5. 2020. 
civilnim vlastima da provedu istragu te preko vojnih vlasti zatražio istragu o djelatnosti šefa srpske vojno-obavještajne službe Dragutina Dimitrijevića Apisa. Istovremeno, vladi u Beču uputio je neizravno, i zbog toga kasnije osporavano, upozorenje. ${ }^{51}$

Slično kao i Dedijer, poznati beogradski povjesničar Andrej Mitrovićs ${ }^{52}$ smatra da „i pored najpažljivijih nastojanja da se takvi podaci prikupe“ ne postoje čvrsti i nedvojbeni dokazi koji bi upućivali na odgovornost službene Srbije za Sarajevski atentat koji je, smatra Mitrović, „organizirala i izvela grupa nacionalnih revolucionara vođena svojim uvjerenjima" i kojima su pomogli neki pripadnici „Narodne odbrane“. Ipak, konstatira Mitrović, atentat je doveo do ratne eskalacije jer je službenom Beču bilo najvažnije da, uz snažnu potporu Njemačke, ovaj događaj iskoristi kako bi mogao „konstruirati rat sa Srbijom“ iako je bio svjestan da „akcija protiv Srbije može odvesti u svjetski rat“. Nasuprot držanju Beča, Mitrović smatra da je službeni Beograd vodio pomirljivu politiku koja ipak nije bila dovoljno popustljiva da bi zadovoljila austrougarske imperijalne ambicije. Za Mitrovićev način gledanja karakteristično je stajalište da je Srbija, koja je iza 1903. imala političku potporu Rusije i financijsku potporu Francuske, bila „žilava i jaka“ politička činjenica koja je ometala austrougarske imperijalne planove na Balkanu. ${ }^{53}$

Nešto drugačiji pogled od Mitrovićeva donosi britanski povjesničar John Keiger $^{54} \mathrm{u}$ svojoj knjizi France and the Origins of the First World War iz 1983. gdje ističe da se u Beču vjerovalo kako iza Sarajevskog atentata stoji opasni „srpski iredentizam", zbog kojeg Austro-Ugarska mora poduzeti ozbiljnu akciju ako ne želi izgubiti status velike sile i postati „bolesnik Europe“. Ipak, bečko uvjerenje da Antanta neće dopustiti izbijanje europskog rata zbog Srbije pokazalo se pogrešnim. U čitavoj stvari važno je imati na umu da je u godinama prije Prvog svjetskog rata Balkan bio poprište napetosti Austro-Ugarske i Rusije pri čemu je Francuska oklijevala bezuvjetno podržati svoju saveznicu Rusiju jer je njezin pogled bio usmjeren na Siriju gdje je, u slučaju raspada Osmanskog Carstva,

51 Vladimir Dedijer, Sarajevo 1914, knjiga II, Beograd, 1978., 106 - 118.

52 Andrej Mitrović (1936. - 2013.), povjesničar sa Sveučilišta u Beogradu, nagrađivan i poznat u Europi i Americi. Radina Vučetić, Andrej Mitrović; umetnost istorije, Godišnjak za društvenu istoriju, 2/2013., Beograd, https://www.slobodnaevropa.org/a/in-memoriam-andrej-mitrovickrticar-vremena-netrpeljivih/25086777.html, posjećeno 31. 5. 2020.

53 Andrej Mitrović, Prodor na Balkan, Beograd, 1981., 21, 31, 424; Andrej Mitrović, Srbija u prvom svetskom ratu, drugo izdanje, Beograd, 2015., 15 - 17.

54 John Keiger, suvremeni britanski stručnjak za europsku povijest XIX. i XX. stoljeća, s naglaskom na francusku vanjsku politiku tog doba. Obrazovanje stekao na Institut d'Etudes Politiques d'Aixen-Provence, u Francuskoj i na University of Cambridge u Velikoj Britaniji. http://usir.salford. ac.uk/profile/2038, posjećeno 31. 5. 2020. 
namjeravala učvrstiti svoj utjecaj. ${ }^{55}$ Sve u svemu, John Keiger smatra da je uloga Srbije u čitavoj stvari sporedna jer je ona bila samo dio složenog i kontroverznog balkanskog konteksta te da najveću odgovornosti za izbijanje rata snosi AustroUgarska i njezina pogrešna računica da će se moći obračunati sa Srbijom bez da izazove opći europski sukob.

Posve drugačije stajalište zastupa poznata američka povjesničarka istočne Europe Barbara Jelavich ${ }^{56}$ u drugom tomu svoje knjige History of the Balkans. Prema Jelavich, u predvečerje Sarajevskog atentata, a nakon pobjede u Balkanskim ratovima, politika Srbije dugoročno je bila usmjerena na teritorijalno širenje i stvaranje Velike Srbije, što je uključivalo „ujedinjavanje južnoslavenskih zemalja u državu koja bi imala potencijala postati velika sila“ i „dominantna snaga na Balkanu“. U takvim okolnostima, ističe Jelavich, „u proljeće i ljeto 1914. Srbija je bila suočena s unutrašnjom krizom oko pitanja sposobnosti vlade da nadzire vojsku“, a posebno „Crnu ruku“ koju je predvodio šef obavještajne službe glavnog stožera pukovnik Dragutin Dimitrijević Apis, koji je sarajevske atentatore, na njihov zahtjev, snabdio oružjem iz srbijanskih državnih arsenala i prokrijumčario ih nazad u Bosnu i Hercegovinu, ali koji nije uspio osigurati njihov povratak kada je vodstvo „Crne ruke“ odlučilo odustati od atentata. Iako je predsjednik beogradske vlade Nikola Pašić o svemu dobio povjerljive obavijesti, nije poduzeo nikakvu službenu akciju nego je, neizravno, upozorio Beč, koji to upozorenje nije shvatio ozbiljno. ${ }^{57}$

U pozadini svega ovoga Jelavich vidi utjecajne beogradske zavjerenike iz 1903. te „Narodnu odbranu“ i „Crnu ruku“ koje smatra izdancima srpske zavjereničke tradicije, na koju je odlučno utjecala znatno učinkovitija bugarska nacionalno-revolucionarna propaganda. U ovakvim okolnostima, svjesni utjecaja Srbije na južne Slavene unutar granica Monarhije, austrougarski dužnosnici nastojali su dokazati izravnu vezu srbijanske vlade i sarajevskih atentatora, u čemu nisu uspjeli, isto kao što nisu uspjeli diplomatski pripremiti teren za ultimatum Srbiji 23. srpnja $1914 .^{58}$

John F. V. KeIger, France and the Origins of the First World War, London, 1983., 90,98 - 101, 119, 121, 146 - 149, 156.

56 Barbara Jelavich (1923. - 1995.). Skupa sa svojim mužem Charlesom bila je američka stručnjakinja za povijest istočne Europe, s naglaskom na Balkan. Barbara and Charles Jelavich papers. University of Indiana, http://webapp1.dlib.indiana.edu/findingaids/view?doc.view=entire text\&docId=InU-Ar-VAD4111, posjećeno 31. 5. 2020.

57 Barbara Jelavich, History of the Balkans. Twentieth Century, volume 2, Cambridge, New York, 1983., $109-111$.

58 B. JELAVICH, History of the Balkans, volume 2,. $109-113$. 
Osam godina kasnije u knjizi Russia's Balkan entanglments 1806 - 1914 Jelavich ističe da je Nikola Pašić, kroz nadzor „Narodne odbrane“, bio upućen u namjere sarajevskih atentatora koji su krajem svibnja 1914. prešli Drinu i otišli izvršiti Sarajevski atentat. Ipak, nakon atentata Pašić nije mogao dopustiti vanjsku istragu koju je u svom ultimatumu tražila Austro-Ugarska, jer je ta istraga mogla „razotkriti sve korake koji su vodili do ubojstva i potvrditi mnoge druge optužbe“. U pozadini ovakvog držanja srbijanskog premijera Jelavich vidi i činjenicu da je tada Srbija izgledala kao jedini pouzdani saveznik Rusije u nastojanju da na Balkanu sačuva svoj prestiž i ostvari svoje strateške interese. ${ }^{59}$ Sve u svemu, Jelavich odgovornost Srbije sagledava u kontekstu zavjereničke djelatnosti „Crne ruke“ i „Mlade Bosne“, za koju je službeni Beograd, u trenutku kada je bio suočen s austrougarskim ultimatumom, vjerojatno znao.

$\mathrm{U}$ tom je smislu puno precizniji britanski povjesničar James Joll ${ }^{60}$ koji u svojoj knjizi The Origins of the First World War iz 1984., čije je treće izdanje 2007. posthumno dopunio kanadski povjesničar Gordon Martel, smatra da je vladu u Beogradu u srpnju 1914. najviše brinulo da austrougarska istraga ne razotkrije opseg njezine izravne ili neizravne umiješanosti u Sarajevski atentat, ali i „razmjere utjecaja koji su Apis i njegova organizacija imali na politički i administrativni život zemlje“. Ovu je situaciju dodatno usložnjavala i činjenica što su Apis i "Crna ruka“ Sarajevski atentat organizirali nedugo nakon eskalacije otvorenog sukoba s predsjednikom vlade Nikolom Pašićem. Prema Jollu, Apis je u takvoj situaciji djelovao „bez stvarne predodžbe o dugoročnim posljedicama ...uklanjanja nekoga koga su smatrali neprijateljem i ugnjetačem srpskog naroda“, jer je vjerovao da je rat između Srbije i Austro-Ugarske ionako neizbježan. Vrlo je karakteristično što Joll smatra da je "Narodna odbrana“ bila nadahnuta „intenzivnim nacionalnim osjećajem“ te da je, uz kulturnu djelatnost u nacionalnom duhu, organizirala i vojnu obuku srpskih mladića iz Bosne i Hercegovine u Srbiji. Rezultat svega je bila, „čitava mreža zavjera i intriga koje još nisu razjašnjene“ i koje u svojoj pozadini imaju terorističkozavjereničke tradicije koje sežu iz turskih vremena. ${ }^{61}$

60 James B. Joll (1918. - 1994 ) je bio britanski povjesničar koji je, među ostalim, predavao na Londonskoj školi ekonomije i Sveučilišstu u Oxfordu.

https://www.history.ac.uk/makinghistory/historians/joll_james.html; https://www.oxforddnb. com/view/10.1093/ref:odnb/9780198614128.001.0001/odnb-9780198614128-e-55059;jsessioni $\mathrm{d}=538$ CF7EE3E4FF2EEC1CC46FDBA6C33E3 Posjećeno 31. 5. 2020.

${ }^{61}$ James Joll, The Origins of the First World War, London, 1984,, 9 - 14, 73; James JoLl, Gordon Martel, The Origins of the First World War, 3rd edition, New York, 2007., 112 - 114. 
Nasuprot Jollu, nedavno preminuli beogradski povjesničar Đorđe Đ. Stankovićc ${ }^{62}$ u svojim knjigama o Nikoli Pašiću i južnoslavenskom ujedinjenju smatra da je u pozadina Sarajevskog atentata „pobjeda jugoslavenske ideje“, a u kontekstu revolucionarno-oslobodilačke borbe. Ipak, Stanković ističe da je u razdoblju prije Sarajevskog atentata Nikola Pašić vjerovao da je Srbiji potrebna barem jedna generacija mirnog razvitka da bi obnovila snage i apsorbirala teritorije osvojene u Balkanskim ratovima zbog čega je neuspješno pokušao postići dogovor s neprijateljski raspoloženim Bečom. Stanković smatra da je Pašić bio upoznat $s$ djelatnošću bosanskih imigranata u Beogradu i njihovom povezanošću sa zavjerenicima iz 1903. koji su tada bili okupljeni oko "Crne ruke“ te da je na svoju ruku, čak i mimo vodstva Radikalne stranke, nastojao otupiti utjecaj zavjerenika s kojima je bio u sukobu i koje nije uspio nadzirati. ${ }^{63}$

Nasuprot Stankoviću, američki povjesničar Samuel R. Williamson ${ }^{64}$ u svom članku o uzrocima Prvog svjetskog rata iz 1988. ističe da vlada Srbije, zbog unutrašnje političkih okolnosti, nije bila spremna surađivati s austrougarskim vlastima oko istrage poslije Sarajevskog atentata jer je taj atentat režirala „skupina utjecajnih srbijanskih vojnih i političkih ličnosti, zakletih pristalica nasilnog rješavanja južnoslavenskog problema“ koja se okupljala oko „Crne ruke“. Williamson zato smatra da je vlada Nikole Pašića za atentat znala unaprijed i da ga je neuspješno pokušala spriječiti. ${ }^{65}$

Tri godine kasnije, Williamson u svojoj knjizi Austria-Hungary and the Origins of the First World War ističe kako je nakon Balkanskih ratova 1912. i 1913. u Beču i Beogradu prevladavalo ratoborno raspoloženje karakteristično za čitavu tadašnju Europu, pri čemu je Srbija, zbog potpore Rusije, u Beču izgledala kao rastuća opasnost. Zato je u proljeće 1914. Beč pozorno motrio unutrašnju krizu u Srbiji koju je prouzročio otvoreni sukob vlade s „Crnom rukom“ i Apisom, koji su stajali iza Sarajevskog atentata. U čitavoj priči Williamson

62 Đorđe Stanković (1944. - 2017.), profesor povijesti na Sveučilištu u Beogradu koji se bavio poviješću nastanka Jugoslavije, posebno ulogom Nikole Pašića čiju ideologiju i političko djelovanje, gledajući iz srpske perspektive, smatrao usmjerenim na ostvarenje južnoslavenskog jedinstva. Latinka Perović, Historian Đorđe Stanković, Prof. PhD (1944-2017), Tokovi istorije, 3/2018., 147, 150, $151,152,156,157,161,162$.

63 Đorđe Đ. Stanković, Nikola Pašić, saveznici i stvaranje Jugoslavije, Beograd, 1984., 21 - 39: Đ. Đ. Stan Ković, Nikola Pašić i jugoslovensko pitanje, sv. 1, Beograd, 1985., $109-141$.

64 Samuel R. Williamson, Jr., američki vojni povjesničar, među ostalim poznat po tome što je zastupa stajalište o kraju „njemačke paradigme“, odnosno kraju desetljetnih rasprava o isključivoj odgovornosti Njemačke za Prvi svjetski rat. https://www.wilsoncenter.org/person/samuel-rwilliamson-jr, posjećeno 7. 4. 2019.

65 Samuel R. Williamson, Jr., The Origins of World War I, Journal of Interdisciplinary History, XVII, 4/1988., 795 - 795, 804, 812. 
važnom smatra ulogu ruskog veleposlanika u Beogradu Nikolasa Hartwiga i činjenicu da je Srbija nakon Balkanskih ratova sve više postajala samostalna balkanska sila koja je manipulirala potporom Rusije. Nakon Sarajevskog atentata, u Beču je početkom srpnja 1914. otkrivena veza atentatora s niže rangiranim dužnosnicima u Beogradu, dok je moguća veza s više rangiranim dužnosnicima ostala nejasna jer izviješće austrougarskog vojnog poslanika u Beogradu Ota Gellineka, koje je otkrivalo pravu bit beogradske zavjere, nije došlo u ruke najviših bečkih dužnosnika koji su tada donosili odluke o ratu i miru. Procjenjujući držanje službenog Beograda, Williamson konstatira kako je Pašić, skupa sa svojim suradnicima, sastavio majstorski odgovor na austrougarski ultimatum od 23. srpnja 1914. koji je zaprepastio vojno i političko vodstvo u Beču jer je bio „pomirljiv, otvoren i skoro pokajnički, ali nepopustljiv u najvažnijem pitanju zajedničke istrage“ jer nije htio dopustiti ugrožavanje državnog suvereniteta Srbije. ${ }^{66}$

Sumirajući svoja stajališta u opširnom eseju o uzrocima Prvog svjetskog rata koji je 2007. napisao s američkim povjesničarom Ernstom R. Mayom, Williamson iznova postavlja stara istraživačka pitanja koja su između dva svjetska rata postavljali Fay, Schmitt i Luigi Albertini i koja su relevantna još i danas. „Jesu li zaposlenici beogradske vlade bili umiješani u zavjeru za organizaciju Sarajevskog atentata; jesu li viši srbijanski dužnosnici imali spoznaje o zavjeri; je li netko pokušao upozoriti Beč;... zašto srbijanska vlada nije ni pokušala uhititi Srbe koji su umiješani u napad?“

Odgovarajući na ova pitanja, Williamson i May ističu da su „vrlo visoko pozicionirani dužnosnici u srbijanskoj vladi znali za zavjeru ali je nisu zaustavili. Uhvaćeni u intenzivnu konfrontaciju s vojskom članovi vlade nisu mogli spriječiti Apisa bez da razotkriju vlastitu krivnju. “67

Slično kao i Williamson, američki povjesničar istočne Europe David MacKenzie $^{68}$ u svojoj poznatoj biografiji Dragutina Dimitrijevića Apisa ističe da je srbijanski premijer Nikola Pašić već početkom 1914. bio svjestan da „veze pukovnika Apisa s revolucionarnim bosanskim učenicima mogu ugroziti Srbiju“ kojoj su nakon Balkanskih ratova bili potrebni obnova i odmor. Štoviše, MacKenzie smatra da se Apis, koristeći svoj položaj glavnog vojnog obavještajca, miješao u kreiranje vanjske politike Srbije, iako mu je za to nedostajalo potrebno

66 Samuel R. Williamson Jr., Austria-Hungary and the Origins of the First World War, 174, 175, 176, 188, 189, 193, 204.

67 Samuel R. Williamson, Ernst R. May, An Identity of Opinion. Historians and July, 350, 353.

68 David MacKenzie (1927.), američki povjesničar, povjesničarski edukator i pisac. https://prabook. com/web/david.mackenzie/311733, posjećeno 31. 5. 2020. 
znanje i iako je bio pristalica terorističkih metoda nacionalne borbe. Zato su informirani krugovi Srbiji Apisa smatrali odgovornim za Sarajevski atentat i jako su žalili što se, kako kaže MacKenzie, „olako igrao vatrom i pomogao zapaliti svjetski rat“. Iza ovakvog Apisova držanja bilo je uvjerenje da je austrougarski prijestolonasljednik Franjo Ferdinand bio vođa „ratne stranke“ u Beču i da bi njegove zamisli o preuređenju Austro-Ugarske mogle zaustaviti njezino slabljenje, odnosno da bi reformirana monarhija na koncu mogla obuhvatiti i Srbiju. Ovaj su strah dijelile i političke elite u Beogradu jer bi reforme Franje Ferdinanda značile kraj ideje Velike Srbije kakvom ju je zamišljao Nikola Pašić. Zbog svega ovoga MacKenzie zaključuje da su postupci Dragutina Dimitrijevića Apisa prije svega bili rezultat pogrešne procjene ciljeva Franje Ferdinanda što je ubrzalo rat koji je Apis atentatom htio odgoditi. ${ }^{69}$

Američki politolog i istraživač ratne povijesti Jack Levy ${ }^{70}$ u svom znanstvenom članku o „srpanjskoj krizi“ koja je prethodila izbijanju Prvog svjetskog rata smatra da je Srbija tada bila sklona očuvanju mira i da je bila spremna na ustupke Austro-Ugarskoj, ali samo do određene granice. U slučaju da ta granica bude prijeđena, „Srbija je davala prednost kontinentalnom ratu u kojem će imati potporu Rusije“, zbog čega Levy smatra da je uloga službenog Beograda „u širenju rata zanemarena" posebno zato što je neposredno nakon Sarajevskog atentata u Europi prevladavala zgroženost nad Srbijom te je austrougarska akcija smatrana legitimnom i očekivanim. No, zbog oklijevanja službenog Beča, taj je legitimitet ubrzo nestao, pa su europski politički lideri počeli Austro-Ugarsku, a ne Srbiju, gledati kao na glavnog rušitelja međunarodnih normi. ${ }^{71}$

Srbijanski povjesničar Vasa Kazimirovićc ${ }^{72}$ u svojoj voluminoznoj knjizi o Crnoj ruci iz 1997. smatra da pripreme za Sarajevski atentat, koje su se odvijale u Beogradu pod pokroviteljstvom ove organizacije, nisu bile nepoznate vojnom i političkom vrhu Srbije. Ipak, on smatra da je ideja o atentatu nikla među mladobosancima te da je u ime „Crne ruke“ s budućim atentatorima kontaktirao

David Mackenzie, Apis: Congenial Cinspirator, New York, 1989., 124, 128, 137. Ova knjiga prevedena je na hrvatski pod naslovom Apis. Čovjek koji je izazvao Prvi svjetski rat, Zagreb, 2014.

70 Jack Levy je profesor međunarodnih odnosa u Rutgers školi znanosti i umjetnosti na Sveučilištu Columbia. Objavio je preko 100 članaka i knjiga u raznim časopisima i knjigama. https://www. polisci.rutgers.edu/cb-profile/jacklevy, https://sipa.columbia.edu/faculty-research/faculty-directory / jack-levy, posjećeno 31. 5. 2020.

71 Jack. S. LeVY, Preferences, Constraints and Choices in July 1914, International Security, vol 15., No. 3, 1990. - 1991., 156, 157, 171, 172.

72 Vasa Kazimirović bio je povjesničar i novinar iz Beograda koji je istraživao bečke arhive i čije su brojne knjige dobile nagrade za publicistiku. Za temu o kojoj je ovdje riječ osim knjige Crna ruka važna je i knjiga Nikola Pašić i njegovo doba koja autoru u trenutku pisanja ovog članka nije bila dostupna. https://www.prometej.rs/autori/vasa-kazimirovic/?script=lat, posjećeno 5. 6. 2020 
Vojislav Tankosić koji ih je snabdio oružjem i organizirao njihovu obuku, dok je vođa "Crne ruke“ Dragutin Dimitrijević Apis čitavo vrijeme pred očima imao obračun s Nikolom Pašićem i dinastijom Karađorđevića. Ipak, prenoseći svjedočanstva spomenutog srbijanskog diplomata Miloša Bogićevića kako je Pašić nekoliko tjedana prije Sarajevskog atentata u povjerljivom dopisu upozorio vojvodu Putnika na opasne veze Apisa s mladobosancima, Kazimirović ističe kako se Apis u ljeto 1914., nakon neuspjelog udara protiv Pašića, pokušao politički približiti prijestolonasljedniku Aleksandru, kako bi spriječio savez Pašića i prijestolonasljednika protiv „Crne ruke“. To, kao i činjenica da su između Apisa i beogradske političke elite već otprije postojali odnosi koji su varirali između pragmatične suradnje do otvorenih sukoba i prijetnji novim državnim udarom, pa čak i vojnom diktaturom, potvrđuje da je beogradski vojni i politički vrh vjerojatno imao precizna saznanja o pripremama za Sarajevski atentat. ${ }^{73}$

U tom smislu spomenute riječi povjesničara S. Williamsona i E. R. Maya kako su članovi beogradske vlade bili „uhvaćeni u intenzivnu konfrontaciju s vojskom i nisu mogli spriječiti Apisa bez da razotkriju vlastitu krivnju“, ${ }^{74}$ predstavljaju najavu historiografskog povrataka na Balkan, odnosno detaljnijeg propitivanja suodgovornosti službenog Beograda za Sarajevski atentat i Prvi svjetski rat.

\section{POVRATAK NA BALKAN (2001. - 2015.)}

Primjer toga propitivanja je britanski povjesničar Hew Strachan ${ }^{75}$ koji u voluminoznom prvom dijelu svoje povijesti Prvog svjetskog rata, objavljenom 2001., ističe kako primarna odgovornost za Sarajevski atentat leži na idealističkim zanesenjacima iz organizacije „Mlada Bosna“ i revolucionarnoj organizaciji „Crna ruka“ čiji je vođa Dragutin Dimitrijević Apis nakon neuspjelog beogradskog prevrata u svibnju 1914. podupro pripreme za atentat da bi ubrzao rat AustroUgarske i Srbije i ponizio predsjednika beogradske vlade Nikolu Pašića. Nakon Sarajevskog atentata Pašić se, zbog vlastite političke slabosti, ustručavao vladi u Beču pružiti potpune informacije o pozadini tog događaja u koji su umiješani i srpski državljani. Ipak, smatra Strachan, beogradski odgovor na austrougarski

73 Vasa Kazimirović, Crna ruka, Kragujevac, 1997., 511 - 517, 620, 739, 740.

74 Samuel R. Williamson, Ernst R. May, An Identity of Opinion. Historians and July, 353.

75 Sir Hew Strachan (1949.), vojni povjesničar i profesor međunarodnih odnosa. Među ostalim predaje na Sveučilištu St. Andrews i Sveučilištu u Oxfordu. Član je Britanske akademije. https://www.standrews.ac.uk/ir/people/strachan/,http://www.csap.cam.ac.uk/network/hew-strachan/ https:// www.thebritishacademy.ac.uk/fellows/hew-strachan-FBA/, https://peoplepill.com/people/hewstrachan/, posjećeno 5. 6.2020. 
ultimatum od 23. srpnja 1914. pokazao se briljantnim pa je Srbija, a ne AustroUgarska, u očima Europe počela izgledati kao oštećena strana. ${ }^{76}$

Nešto preciznija stajališta donosi već spomenuta britansko-njemačka povjesničarka Anika Mombauer ${ }^{77}$ koja ističe kako je u historiografiji postignut konsenzus da Njemačka snosi najveći dio, ili barem vrlo veliki dio krivice, „ali da politiku ostalih europskih vlada također treba uzeti u obzir kako bi se donijela poštena prosudba“. U tom smislu ona smatra da su „balkanske tenzije“ u godinama neposredno prije Prvog svjetskog rata bile „od presudne važnosti“, pri čemu vlada u Beogradu, usprkos tomu što je vrlo pažljivo i pomirljivo formulirala odgovor na austrougarski ultimatum od 23. srpnja 1914., nije bila u „pomirljivom raspoloženju“, odnosno da je „sasvim jasno da je bila svjesna posljedica svoga odgovora“,jer je satima prije predaje odgovora započela pripreme za mobilizaciju. Zato, smatra Mombauer, odgovor na pitanje o razini suodgovornosti Srbije treba tražiti u kontekstu napetosti nakon Balkanskih ratova 1912. i 1913. te u okviru činjenice da je barem dio beogradske vlade bio upućen u planove za Sarajevski atentat. ${ }^{78}$

Slično kao i Mombauer, američki povjesničar Balkana Richard C. Hall ${ }^{79} \mathrm{u}$ znanstvenom članku iz 2003. smatra da su premijer Nikola Pašić i neki članovi njegove vlade od početka lipnja 1914. bili svjesni da „Crna ruka“ sprema atentat u Sarajevu, ali da je istraga koja je pokrenuta ostala bez rezultata zbog otpora srpske vojske, ali i zbog straha vlade da ne razotkrije vlastitu obavještajnu mrežu u Bosni i Hercegovini. Ipak, skidajući izravnu odgovornost s leđa Srbije, Hall ističe kako Sarajevski atentat nije potakao globalni sukob koji je uslijedio, nego je upotreba ovog događaja od strane Austro-Ugarske odvela narode Europe u rat, pri čemu ključnim smatra austrougarski ultimatum Srbiji od 23. srpnja 1914. koji je svojim „strašnim zahtjevima doveo do angažmana pet velikih sila“. 80

76 Hew Strachan, The First World War, volume I, New York, 2001., 65 - 68, 80.

77 Anika Mombauer, profesorica moderne europske povijesti na Otvorenom sveučilištu u Milton Keynesu u Velikoj Britaniji. Posebno se bavi istraživanjem Prvog svjetskog rata i njegovih uzroka o čemu je napisala brojne knjige i znanstvene članke. Bila je članica uredničkog odbora online Enciklopedije Prvog svjetskog rata. http://www.open.ac.uk/people/am438, https:// encyclopedia.1914-1918-online.net/contributors/Annika_Mombauer, posjećeno 5. 6. 2020.

78 Anika Mombauer, The Origins of the First World War, London, 2002., 12, 12, 206, 208, 223, 224, 270. Ova knjiga prevedena je na hrvatski pod naslovom Uzroci Prvog svjetskog rata, Zagreb, 2014.

79 Richard Hall, profesor povijesti na Sjeverozapadnom sveučilištu Georije u SAD-u. Za temu o kojoj je ovdje riječ posebno je zanimljivo što se Hall bavi istraživanjem ratova na Balkanu, a posebno Balkanskih ratova. https://www.hist.auth.gr/en/macedonianfrontconference/richardhall, posjećeno 6. 6. 2020.

80 Richard C. Hall, Serbia, u: The Origins of World War I, ur. Richard F. Hamilton, Holger. H. Helwig, Cambridge, New York, 2003., 107 - 111. 
Nasuprot ovomu, nedavno preminuli američki povjesničar David Fromkin ${ }^{81}$ smatra da je Kraljevina Srbija ne samo skrivala nego i poticala terorističku djelatnost protiv Austro-Ugarske, zbog čega austrougarski ultimatum od 23. srpnja 1914. smatra opravdanim. Povlačeći analogiju sa slučajem onodobnog Meksika i SAD-a, Fromkin ističe da ,ako je vlada nemoćna provesti zakon unutar svoga teritorija, ako ne može spriječiti upotrebu svog teritorija za nanošenje štete drugoj zemlji, onda ona gubi pravo da se njena suverenost poštuje“.$^{82}$

Nasuprot Fromkinu, američki povjesničar Jay Winter ${ }^{83} \mathrm{i}$ francuski povjesničar Antonie Prost ${ }^{84} \mathrm{u}$ već spomenutoj knjizi o kontroverzama oko izbijanja Prvog svjetskog rata iz 2005. ističu da je Sarajevski atentat izvršio „srpski nacionalistički učenik“, ali ne spominju ni Apisa, ni „Crnu ruku“, ni beogradsku obavještajnu mrežu u Bosni i Hercegovini. Također, gledajući čitavu stvar iz perspektive francuske historiografije, autori ističu kako je Srbija tada bila smetnja širenju utjecaja Austro-Ugarske na Balkan, ali i opasnost za njezinu unutrašnju stabilnost. Pri tome je Beč posebno opasnim smatrao „žestoke nacionaliste“ („virulent nationalists") iz Srbije koji su čak i izravno ugrožavali interese Austro-Ugarske. Ovakvo stanje stvari, smatraju autori, bilo je u pozadini neprihvatljivog bečkog ultimatuma od 23. srpnja 1914. zamišljenog kao uvod u lokalizirani rat kojim je Austro-Ugarska namjeravala „srediti račune“ sa Srbijom, što je na koncu dovelo do sloma ravnoteže među velikim silama i rata. ${ }^{85}$

Odgovornost službene Srbije negira i srbijanski povjesničar Radovan M. Drašković ${ }^{86}$ u knjizi Pretorijanske težnje u Srbiji iz 2006. u kojoj ističe da Nikola Pašić i njegova vlada nisu sudjelovali u pripremama za Sarajevski atentat niti su o njima išta znali. Štoviše, smatra Drašković, članovi vodstva „Crne ruke“ imali su dvojbe oko opravdanosti atentata koji je Apis sponzorirao kao privatna osoba,

81 David Fromkin (1932.), profesor prava sa Sveučilišta u Bostonu koji je, među ostalim, istraživao i međunarodne odnose. Za temu o kojoj je ovdje riječ važno je njegovo istraživanje sudbine Bliskog istoka u kontekstu raspada Osmanskog Carstva https://www.encyclopedia.com/arts/educationalmagazines/fromkin-david-1932, posjećeno 6. 6. 2020.

82 David From kin, Europe's Last Summer. Who started Great War in 1914., 2004., 265.

83 Jay Winter (1945.), profesor britanske i europske povijesti na Sveučilištu Yale. Za temu o kojoj je ovdje riječ zanimljivo je što je Winter stručnjak za Prvi svjetski rat. https://history.yale.edu/ people/jay-winter, posjećeno 6. 6. 2020.

84 Antonie Prost (1933.), profesor povijesti sa Sveučilišta Panthéon Sorbonne u Parizu. https://www. pantheonsorbonne.fr/unites-de recherche/crhxix/directoryofprofessorsandresearchdirectors/ prost-antoine/. https://www.fnac.com/Antoine-Prost/ia7445/bio, posjećeno 6. 6. 2020.

85 Jay Winter, Antonie Prost, The Great War in History, Cambridge, 2005., 37, 38.

86 Radovan M. Drašković (1877. - 1974), istraživač lokalne povijesti grada Valjeva u Srbiji i povijesti Srbije u XIX. i XX. stoljeću. Osim knjige o Dragutinu Dimitrijeviću Apisu i „Crnoj ruci“, napisao još 13 naslova. https://www.worldcat.org/identities/lccn-n88299887/, posjećeno 6. 6. 2020. 
mimo „Crne ruke“ i mimo svog položaja glavnog vojnog obavještajca. Kada je vodstvo „Crne ruke“, u zadnji čas, pokušalo opozvati sarajevske atentatore, pokazalo se da su ovi mladići djelovali vrlo samostalno. Drašković smatra da je Sarajevski atentat iz Apisove perspektive bio povezan sa strahom od namjera Franje Ferdinanda, za kojeg se vjerovalo da svojom nazočnošću na vojnim vježbama u okolici Sarajeva krajem lipnja 1914. najavljuje napad austrougarske vojske na Srbiju koja je bila iscrpljena Balkanskim ratovima. S druge strane, Apisova potpora sarajevskim atentatorima bila je povezana i s političkoprevratničkom borbom protiv Nikole Pašića i Radikalne stranke. U pozadini svega je bila Apisova namjera da nadzire ne samo unutrašnju nego i vanjsku politiku Srbije zbog čega Drašković smatra da su Apis i „Crna ruka“ bili opasni zavjerenici koje je srpski politički vrh uspio ukloniti tek u izbjeglištvu tijekom Prvog svjetskog rata. ${ }^{87}$

Iste godine kad i Drašković, srbijanski povjesničar Milorad Belićs8 objavio je knjigu o jednom od ključnih organizatora Sarajevskog atentata Vojislavu Tankosiću koji je, zbog osobne naglosti i sklonosti nasilnim i revolucionarnim rješenjima, podupro zamisao sarajevskih atentatora, a sve mimo znanja beogradske vlade. Kada je Nikola Pašić, preko svojih obavještajnih kanala, doznao za čitavu stvar i pokušao zaustaviti atentatore, nije uspio jer su i srbijanski granični časnici bili angažirani u tajnoj mreži „Crne ruke“. U tom je smislu vrlo zanimljivo Belićevo zapažanje da su četnici i „Mlada Bosna“ bili revolucionarne organizacije čiji su se ciljevi podudarali i čije su veze sezale još u doba krize oko austrougarske aneksije Bosne i Hercegovine 1908., zbog čega odbacuje pretpostavku da je čitava stvar oko Sarajevskog atentata zapravo bila usmjerena na rušenje Nikole Pašića i njegove vlade. Dakle, smatra Belić, u čitavoj stvari najveću odgovornost snose Tankosić i „Crna ruka“. ${ }^{89}$

Nasuprot Beliću, britanski povjesničar istočne Europe Robin Okey, ${ }^{90}$ iako se izravno ne bavi Sarajevskim atentatom i suodgovornošću Srbije, u svojoj knjizi Taming Balkan nationalism iz 2007. ističe da su Gavrilo Princip i mladobosanci bili socijalno marginalizirani pojedinci, zaneseni srpskom nacionalnom

87 Radovan M. Drašković, Pretorijanske težnje u Srbiji, Beograd, 2006., 194 - 200, 203, 204, $231-274$.

88 Milorad Belić, pisac i autor koji je istraživao srbijansku povijest XX. stoljeća o čemu je, osim životopisa Vojina Tankosića, napisao još 11 naslova. http://worldcat.org/identities/ lccn-n2010056479/, posjećeno 6.6.2020.

89 Milorad Belić, Komitski vojvoda Vojislav Tankosić, Valjevo, 2005., 48 - 52, 78.

90 Robin Okey (1942.), umirovljeni povjesničar istočne Europe sa Sveučilišta Warwick u Walesu. Za temu o kojoj je ovdje riječ zanimljivo je što je Okey istraživao kulturnu politiku Austro-Ugarske. https://warwick.ac.uk/fac/arts/history/people/staff_index/rokey/, posjećeno 6. 6.2020. 
predajom, koji su, usprkos kulturološkoj, anarhističkoj i modernističkoj pobuni protiv starijih naraštaja, u izvjesnoj mjeri ipak bili oruđe srbijanskih elita. To se na prvom mjestu odnosi na beogradsku vojno-obavještajnu službu, odnosno srpske iredentističke organizacije "Narodna odbrana“ i "Crna ruka“ koje su mladim atentatorima dale oružje i tajnim kanalima prebacili ih u Bosnu i Hercegovinu. Zato Okey smatra da je beogradska vlada znala što se sprema, tim više što su mnogi mladobosanci prošli vojnu obuku u Srbiji. U pozadini svega on vidi „duboki sukob između habsburške i srpske ideje“ te činjenicu da su „srpski intelektualci do Prvog svjetskog rata prihvatili jugoslavizam... zadržavajući pri tome svoje poglede na posebnu sudbinu Srba“, zbog čega su odgovorni pojedinci u vrhu Austro-Ugarske „bili sve više frustrirani provalom nacionalnih i društvenih problema“, što je značilo postojanje izraženog nepovjerenja prema Srbima, posebno zato što se Srbija nakon Balkanskih ratova među južnoslavenskim podatcima Austro-Ugarske afirmirala kao Pijemont, odnosno kao središte južnoslavenskog ujedinjenja. ${ }^{91}$

Nasuprot ovomu, američki politolog Frank C. Zagare ${ }^{92}$ u svojim znanstvenim člancima iz 2009. i u knjizi Games of July objavljenoj 2011., razmatrajući uzroke Prvog svjetskog rata kroz matematičku teoriju igara, smatra da Austro-Ugarska nije imala dovoljno dokaza za upiranje prstom u službeni Beograd, iako je izvjesno da je Nikola Pašić imao određene spoznaje o atentatu koji je pripreman i u Beogradu. U takvoj situaciji, smatra Zagare, pogrešnom se pokazala bečka računica da Sarajevski atentat može upotrijebiti za konačni obračun sa Srbijom koja je sve više izgledala kao opasna strateška ugroza jer bi balkanski status quo nakon Bukureštanskog mira 1913. značio početak urušavanja Austro-Ugarske pod utjecajem etničkog iredentizma iz Beograda. Bečje, prema njegovu mišljenju, u srpnju 1914. počinio pogrešku propustivši bolje razmotriti poziciju Rusije koja, zbog vlastitog prestiža, nije mogla napustiti Srbiju. Sažimajući svoj stav o suodgovornosti Srbije, Zagare ističe kako je Sarajevski atentat bio teroristički čin koji je, „iako nije bio sponzoriran od strane državnih vlasti, ipak bio potaknut od strane pojedinaca u beogradskoj obavještajnoj zajednici“, koja je time zapalila iskru potpunog kolapsa europskog sustava ravnoteže velikih sila. ${ }^{93}$

91 Robin OKey, Taming Balkan nationalism, New York, 2007., 211 - 216, 230, 232.

92 Frank C. Zagare, politolog s američkog Sveučilišta Buffalo. Za temu o kojoj je ovdje riječ zanimljivo je što Zagare, među ostalim, istražuje međunarodne konflikte, eskalacije ratova i primjenu teorije igara na međunarodne odnose. http://arts-sciences.buffalo.edu/political-science/faculty/ department-faculty/frank-c-zagare.html, posjećeno 6. 6.2020.

93 Frank C. ZAGARE, Explaning the 1914 War in Europe, Journal of Theoretical Politics, 21 (1), 2009. 63 - 95; Frank C. ZAGARE, After Sarajevo: Explaining the Blank Check, International Interactions, 35/ 2009., 106, 112, 113, 121; Frank C. ZAGARE, The Games of July, Ann Arbor, 2011., 94, 98, 189. 
U tom smislu ne treba čuditi što je u najnovije vrijeme britanski povjesničar Sean McMeekin ${ }^{94}$ fokus istraživanja uzroka Prvog svjetskog rata skrenuo prema Rusiji, Francuskoj i, posredno, Srbiji. U knjizi The Russian Origins of the First World War iz 2011. McMeekin ističe kako, da bi se ispravno procijenila odgovornost Srbije, „valja raspetljati ne samo ono što se doista dogodilo nego i što su relevantni donosioci političkih odluka znali (ili su mislili da znaju) i kad su znali“. U tom smislu on važnom smatra činjenicu da je "Crna ruka“ obučila i opremila Gavrila Principa i dvojicu sarajevskih atentatora iza čega je stajao šef srpske vojno-obavještajne službe Dragutin Dimitrijević Apis čiji postupak dokazuje odgovornost „poluslužbene Srbije“. U pozadini svega je, smatra McMeekin, bila strateška računica Rusije koja Austro-Ugarskoj nije htjela dopustiti da raskomada, kako se kasnije govorilo, „malu hrabru Srbiju“. Ipak, on „ironijom srpanjske krize 1914.“ smatra to što se Rusija nepromišljeno upustila u rat zbog Srbije, iako je njezina najvažnija strateška preokupacija bilo pitanje Carigrada i tjesnaca između Crnog mora i Sredozemlja. S druge strane, vrlo bizarnim smatra postupak službenog Beča koji je većinu svojih optužbi pogrešno usmjerio protiv „Narodne odbrane“ iako su postojali vjerodostojni dokazi za odgovornost „Crne ruke“ koja je bila zaista kriva za Sarajevski atentat, a koji su austrougarskim optužbama protiv Srbije mogli dati uvjerljivost. ${ }^{95}$

Tri godine kasnije u drugom izdanju knjige July 1914. Countdown to War McMeekin ističe da, usprkos brojnim nepoznanicama oko toga što su politički vođe u Beogradu zaista znali o planovima „Crne ruke“, prema riječima tadašnjeg ruskog vojnog poslanika u Srbiji, „u tadašnjem malom Beogradu... zavjera nije mogla biti tajna“. Štoviše, McMeekin smatra da su visoki srbijanski dužnosnici bili umiješani u Sarajevski atentat koji predsjednik beogradske vlade Nikola Pašić nije ni pokušao spriječiti niti je kasnije proveo pravu istragu o okolnostima u kojima je atentat organiziran. Ipak, McMeekin ističe da Gavrilo Princip i njegovi suzavjerenici snose konačnu odgovornost za izazivanje „srpanjske krize“, s tim da ni Princip ni „Crna ruka“ nisu ubojstvom nadvojvode Franje Ferdinanda namjeravali izazvati svjetski rat. ${ }^{96}$

94 Sean McMeekin, profesor europske povijesti i kulture na Bard Collegeu u New Yorku. Za temu o kojoj je ovdje riječ važno je spomenuti da se McMeekin osim povijesti Rusije u XX. stoljeću bavio i Osmanskim Carstvom i bliskoistočnim pitanjem. http://historicalstudies.bard.edu/faculty/, posjećeno 6. 6. 2020.

95 Sean McMenkin, The Russian Origins of the First World War, Cambridge, 2011., 27, $42,258$.

96 Sean McMee Kin, July 1914. Countdown to War, London, 2014., 50, 51, 390, 391. 
Slično McMeekinu, australsko-britanski povjesničar Cristopher Clark ${ }^{97} \mathrm{u}$ spomenutoj knjizi The Sleepwalkers. How Europe Went to War in 1914 ističe da je danas mnogo jasniji „balkanski kontekst početka rata“ i da je „Srbija je jedna od slijepih točaka" u historiografskim raspravama oko njegova izbijanja. Zbog toga, smatra Clark, „stavljanje Sarajeva i Balkana nazad, u središte priče, ne znači demoniziranje Srba ili njihovih državnika, niti nas oslobađa od obveze da razumijemo vanjske i unutrašnje sile koje su djelovale na one srpske političare, časnike i aktiviste čije je ponašanje i odluke koje su donijeli, doprinijelo određivanju posljedica pucnjeva u Sarajevu“ koji su "do sada se tretiralo samo kao predtekst, koji je imao ograničeni utjecaj na izbijanje rata“. Clark smatra kako danas, u promijenjenim okolnostima na početku 21. stoljeća, neke stvari vidimo jasnije nego naši predci prije stotinu godina, posebno zbog toga što je „od Srebrenice i opsade Sarajeva teško misliti o Srbiji kao o žrtvi politike velikih sila i može je se gledati kao silu koja ima vlastite ciljeve i snagu“. U tom smislu Clark ističe da je Nikola Pašić vrlo vjerojatno već krajem svibnja ili početkom lipnja 1914. dobio dojave o atentatu is dosta zakašnjenja, četiri dana prije Sarajevskog atentata, naredio istragu te, na vrlo neizravan način, upozorio službeni Beč. ${ }^{98}$

Slično kao i Clark, britanska povjesničarka Margareth MacMillan ${ }^{99}$ u svojoj knjizi War that ended the peace iz 2013. smatra da "Srbija nije bila u stanju i u najvećoj mjeri nije bila ni voljna obuzdati različite nacionalističke organizacije koje su agitirale među južnim Slavenima u Austro-Ugarskoj“, a koje su novac i oružje dobivale od srpske vojske, što znači da je predsjednik beogradske vlade bio upućen u pozadinu Sarajevskog atentata. Ipak, smatra MacMillan, Pašić je odbio prihvatiti suodgovornost službenog Beograda za Sarajevski atentat koji su izveli idealistični i strastveni mladi revolucionari snažno nadahnuti ruskim anarhizmom. U napetom ozračju nakon atentata, smatra MacMillan, samo je utjecajni ruski veleposlanik u Beogradu Nikolas Hartwig, koji je umro nedugo

97 Christopher Clark, profesor europske povijesti, intelektualne povijesti i povijesti političke misli na Sveučilištu Cambridge. Za temu o kojoj je ovdje riječ važno je njegovo istraživanje povijesti Prusije, odnosno ujedinjene Njemačke. https://www.hist.cam.ac.uk/directory/cmc11@cam. ac.uk, posjećeno 6.6.2020.

98 Christopher Clark, The Sleepwalkers. How Europe Went to War in 1914., London, 2012., XXVI, XXVII, XXVIII, 59, 60. Ova knjiga prevedena je na hrvatski pod naslovom Mjesećari: kako je Europa krenula u rat, Zagreb, 2018.

99 Margaret MacMillan je, među ostalim, profesorica međunarodne povijesti na Sveučilištu u Oxfordu i profesorica povijesti na Sveučilištu u Torontu. Bavi se i istraživanjem povijesti Britanskog imperija, https://www.history.ox.ac.uk/people/professor-margaret-macmillan. http://www. margaretmacmillan.com/Bio.php, posjećeno 6.6.2020. 
prije uručenja austrougarskog ultimatuma, mogao odlučno utjecati na vladu Srbije da prihvati i najpretjeranije austrougarske zahtjeve. ${ }^{100}$

Puno kompleksniji pogled na problem suodgovornosti Srbije za Sarajevskog atentata i Prvi svjetski rat donosi suvremena beogradska povjesničarka prava Olga Popović-Obradović1 ${ }^{101}$ u knjizi The Parliamentary system in Serbia 19031914 objavljenoj 2013. Analizirajući parlamentarni sustav Kraljevine Srbije uspostavljen iza prevrata 1903., ona zavjerenike iz organizacije "Crna ruka“, ali i vojni vrh Srbije općenito, smatra „izvan ustavnim činiocima“ koje tadašnji predsjednik vlade Nikola Pašić, iako je u zakulisnim borbama s njima zadržao vlast, nije smogao snage u cijelosti nadzirati. Također, autorica smatra da je tadašnja „politika nacionalnog ujedinjenja i teritorijalnog širenja... značila da je Srbija razdoblje od 1903. do 1914. potrošila ili vodeći rat ili se pripremajući za rat“ zbog čega je u predvečerje Prvog svjetskog rata vojska imala toliki utjecaj da je otvorenije nego prije dovodila u pitanje ustavno uređenje zemlje. ${ }^{102}$ Sve $u$ svemu, Popović-Obradović smatra da iza Sarajevskog atentata i suodgovornosti Srbije za Prvi svjetski rat stoji vrh srbijanske vojske i razni „izvan ustavni činioci“, a posebno revolucionarno-teroristička djelatnost „Crne ruke“.

Nasuprot ovomu, nedavno preminuli srbijanski povjesničar Dušan T. Bataković103 kao jednostrana odbacuje stajališta Seana McMeekina, Christophera Clarka i Margaret MacMillan tvrdeći da „skoro postoji konsenzus među ozbiljnim znanstvenicima da je aneksijska kriza 1908., a ne stav Srbije 1914., dovela do rata“. Pri tome je karakteristično što Bataković smatra da je u doba Sarajevskog atentata "Crna ruka“ već bila nefunkcionalna, odnosno „preminula“, te da su njezini bivši članovi, na čelu s Vojinom Tankosićem, kao privatne osobe pomagali mladobosanskim atentatorima da bi zagorčali život predsjedniku beogradske vlade Nikoli Pašiću, ali i uplašili austrougarskog prijestolonasljednika Franju Ferdinanda. Bataković također smatra da je vlada u Beogradu, nakon što je dobila obavijesti o tome da se priprema atentat na Franju Ferdinanda, reagirala brzo, odnosno da je Nikola Pašić naredio da civilne vlasti

100 Margareth MacMillan, War that ended the peace, London, 2013., 465, 514, 533, 534.

101 Olga Popović-Obradović (1954. - 2007.) bila je profesorica države i prava na Pravnom fakultetu u Beogradu. Za temu o kojoj je ovdje riječ važno je njezino istraživanje povijesti parlamentarizma u Srbiji. http://www.ius.bg.ac.rs/informacije/biografija\%20olga\%20popovic.htm, posjećeno 16. 4. 2019.

102 Olga Popović-Obradović, The Parliamentary system in Serbia 19031914, Beograd, 2013., 586 588.

103 Dušan T. BATAKović (1957. - 2017.), bivši ravnatelj Balkanološkog instituta SANU u Beogradu. Istraživao je povijest Srbije i Balkana te srpsko-albanske odnose, s naglaskom na problem Kosova. http://www.batakovic.com/curriculum-vitae.html, posjećeno 6. 6. 2020. 
provedu istragu i od glavnog stožera srpske vojske zatražio potpuno izvješće o djelatnosti Dragutina Dimitrijevića Apisa i drugih časnika povezanih s „Crnom rukom“. Reakciju Austro-Ugarske na Sarajevski atentat Bataković vidi kao uvod u dugo planirani rat protiv Srbije. ${ }^{104}$ Vrlo je karakteristično što Bataković smatra da je glavni uzrok sukoba Srbije i Austro-Ugarske pitanje Bosne i Hercegovine čije je oslobođenje, u kontekstu beogradskog povratka na politiku „Načertanija“ i obnovljenog prestiža Srbije među južnim Slavenima u Austro-Ugarskoj, bilo važan element tadašnje srbijanske politike, ali i važan motiv zavjereničke djelatnosti mladobosanskih aktivista. ${ }^{105}$

Slično kao i Bataković, beogradski povjesničar Mile Bjelajac ${ }^{106}$ u svom opširnom znanstvenom članku iz 2013. ističe da beogradska vlada nije bila upoznata s planovima "Crne ruke“ i da je, nakon pobjede u Balkanskim ratovima, bila sklona dobrim odnosima s Austro-Ugarskom kako bi dobila duže razdoblje mira potrebnog za oporavak. Bjelajac također smatra da umiješanost „Crne ruke“ u Sarajevski atentat, zbog nedostatka izvornih dokumenata, nije nepobitno dokazana, zbog čega „povjesničari ne oskudijevaju u teorijama“ koje su rezultat propagandnih potreba Njemačke i Austro-Ugarske, ali i osobnih, antisrpskih animoziteta pojedinih autora. On zato smatra da pisanje dijela današnje historiografske produkcije „karakterizira pokušaj namjernog sklanjanja u stranu već utvrđenih činjenica o utjecaju međuratne politike njemačkih vlada na skidanje odgovornosti za rat pod svaku cijenu“. 107

Zato Bjelajac u svojoj prethodno spomenutoj knjizi 1914-2014. Zašto revizija?, iz 2014., pomno i detaljno dokazuje da Srbija nije odgovorna za Prvi svjetski rat, polazeći sa stajališta o apsolutnoj krivnji Njemačke i Austro-Ugarske. Pri tome on aktualizira gledište da Balkan i Srbija u ovoj priči nisu toliko važni, odnosno da glavnim uzrokom Prvog svjetskog rata valja smatrati agresivnu težnju Trojnog saveza za dominacijom na račun Antante, čime je bila poremećena vojnopolitička ravnoteža snaga u tadašnjoj Europi. Srbija je u takvim okolnostima,

104 Dušan T. Bataković, The Salonica trial 1917. Black Hand vs Democrarcy, u: The Salonica Theatre of operation and the outcome of Great War, Institute for Balkan studies, 277 (2005.), 281; Dušan T. Bataković Storm over Serbia. The Rivalry between Civil and Military authorities (1911. - 1914.), Balcanica, 54/2013., 349, 350.

105 Dušan T. Bata ković, Prelude to Sarajevo. The Serbian Question in Bosnia and Herzegovina 1878.1914., Balcanica, XXVII, 1996., 117 - 155.

106 Mile Bjelajac (1955.), ravnatelj Instituta za noviju historiju Srbije. Bavi se poviješću Jugoslavije, posebno njezine vojske. http://www.inisbgd.co.rs/en/saradnici/25-dr-mile-bjelajac.html, posjećeno 6. 6. 2020.

107 Mile Bjelajac, Novi (stari) zapleti oko uzroka Prvog svetskog rata pred obeležavanje 100. godišnjice, Tokovi istorije, svezak br. 1, 2013., 15, 19 - 36, 39. 
slično kao Belgija i Luksemburg, bila žrtva koja se našla na putu osvajačkih ambicija Austro-Ugarske, odnosno Njemačke. U prilog ovim tvrdnjama Bjelajac ističe kako je u tadašnjem beogradskom političkom vrhu postojala „odsutnost želje za ratom“ jer je „Srbiji trebalo najmanje deset godina mira, ako ne i višs“. 108 Sažimajući svoj stav Bjelajac postavlja sljedeće pitanje: „Kako to da je za Europu najopasniji bio mali srpski nacionalizam i imperijalizam?"“109

Uz ovo pitanje on veže i sljedeću moralnu dvojbu: „Kako se Srbija našla u situaciji da najglasniji trendovi revizije danas budu kao i glasovi u medijima centralnih sila 1914. i 1941. godine. Kakve su to vrijednosti u pitanju koje daju moralno pravo velikima da okupiraju, anektiraju i civiliziraju, a u isto vrijeme to pravo nemaju manji... Kao da se cijeli svijet vratio političkim mentalitetima od prije stotinu godina...", što iz njegove perspektive izgleda kao obnova starog zapadnjačkog imperijalizma. ${ }^{110}$

Nasuprot Bjelajcu, britanski povjesničar Marvin Benjamin Fried ${ }^{111}$ u svojoj knjizi Austro-Hungarian War Aims in the Balkans during World War I iz 2014. ističe da je Srbija, usprkos tomu što je vodila rat za opstanak u kojem je imala ogromne žrtve, pokušala ostvariti velikosrpske ideale, koji su obuhvaćali stjecanje Bosne i Hercegovine, Hrvatske i Slovenije koji su bili ostvarivi samo uništenjem Austro-Ugarske čiji su vojni ciljevi samo prividno bili kaznena ekspedicija protiv Srbije. U stvarnosti glavni austrougarski cilj bio je ponovno učvrstiti svoj prestiž na Balkanu, učvrstiti Albaniju i spriječiti prodor sila Trojne Antante na ovo područje. Ipak, ističe Fried, pod utjecajem rata koji nije bio lokalnog karaktera kako se priželjkivalo u Beču i pod utjecajem Njemačke, cilj je postao „potpuna pobjeda nad Srbijom“ i „eliminacija velikosrpske ideje“, odnosno slabljenje Srbije podjelom dijela njezina teritorija između Bugarske, Albanije i Austro-Ugarske. ${ }^{112}$

Slično misli i već spomenuti austrijski povjesničar Manfried Rauchensteiner. ${ }^{113}$ On u svojoj knjizi The First World War and the End of the Habsburg Monarchy

108 Mile Bjelajac, 1914-2014: Zašto revizija?, Beograd, 2014., 7, 34, 35, 38, 40.

109 M. BJELAJAC, 1914-2014: Zašto revizija?, 7.

110 M. BJELAJAC, 1914-2014: Zašto revizija?, 7, 8.

111 Marvin B. Fried, profesor povijesti Prvog svjetskog rata i XX. stoljeća na Londonskoj školi ekonomije. Bavi se istraživanjem Trojnog saveza, a posebno Austro-Ugarskom i njezinom ulogom na Balkanu. http://www.lse.ac.uk/International-History/People/GTA-GT/fried/fried. Posjećeno 6.6. 2020 .

112 Marvin Benjamin FRIED, Austro-Hungarian War Aims in the Balkans during World War I, London, 2014., 11, 13, 24, 26, 30, 31.

113 Manfried Rauchensteiner (1942). Profesor austrijske i suvremene povijesti na Sveučilištu u Beču. Bavio se i vojnom poviješću. https://www.da-vienna.ac.at/en/The-Academy/About-theAcademy/Faculty/MoreInformation/Id/40/RAUCHensteineR-Manfried. Posjećeno 6. 6. 2020. 
objavljenoj 2014. odgovornost Srbije, ali i Balkana općenito, sažima tvrdnjom kako je „spontana agresivnost i iracionalno ponašanje koji su se manifestirali na Balkanu“ bili važan okidač za eksploziju napetosti između Austro-Ugarske i Njemačke s jedne strane i Francuske i Rusije s druge strane. Pri tome Rauchensteiner „Mladu Bosnu“ smatra velikosrpskim pokretom čiji su članovi namjeravali srušiti Habsburšku Monarhiju kako bi stvorili Jugoslaviju i koji su bili čvrsto povezani s „Crnom rukom“ koja im je pomogla pripremiti Sarajevski atentat. Istovremeno, „oni koji su bili na vlast u Srbiji nisu bili voljni priznati da je, doslovno pred očima vlade, stvorena mreža koja je promicala jasan cilj uništenja Austro-Ugarske“, iza koje je stajao čelni čovjek tajne vojne službe Srbije Dragutin Dimitrijević Apis. Iako je beogradska vlada nakon Sarajevskog atentata pokazala jasnu volju za suradnjom, ta je suradnja bila „nevoljka i površna“ pa Rauchensteiner smatra da držanje Beča u srpnju 1914. nije bilo rezultat „iracionalne zbrke, krvožednosti i osvetoljubivosti“, nego posljedica „brojnih iskustava, pretpostavki i osjećaja“ koje proizlazi i iz iskustava s tadašnjom balkanskom politikom općenito, kako se Srbiji ne može vjerovati i da je s njom nemoguće pregovarati bez rata. ${ }^{114}$

Nasuprot Rauchensteineru, kanadski povjesničar Gordon Martel ${ }^{115}$ u svojoj knjizi The Month that changed the World. July 1914 objavljenoj 2014. smatra da se "može pokazati nemogućim dokazati suodgovornost srbijanske vlade“ za Sarajevski atentat, iako „je bilo jasno da je zavjera bila dobro organizirana i da se njeni konci mogu pratiti do Beograda“ gdje je vlada preko svojih povjerljivih ljudi znala za pripreme za atentat. Iako je predsjedniku beogradske vlade Nikoli Pašiću nesumnjivi cilj bio „sve južne Slavene ujediniti pod svojim zastavom“, on je, smatra Martel, istovremeno nastojao popraviti odnose s Austro-Ugarskom jer je Srbiji bilo potrebno duže razdoblje mira kako bi konsolidirala dobitke iz Balkanskih ratova. Osim toga, Pašić je prije Sarajevskog atentata bio suočen s mogućim udarom „najvatrenijih nacionalista“iza kojih su stajali visoko rangirani srbijanski vojni časnici. Važnim elementom ove priče Martel smatra i „Narodnu

114 Manfried Rauchensteiner, The First World War and the end of the Habsburg Monarchy, Wien, Köln, Weimar, 2014., 17, 86, 87, 92, 102. Ova knjiga prevedena je na hrvatski pod naslovom Prvi svjetski rat i kraj Habsburške Monarhije, Zagreb, 2019.

115 Gordon Martel, umirovljeni profesor emeritus povijesti sa Sveučilišta Sjeverna Columbia. Među ostalim je istraživao britansku vanjsku politiku i uzroke Prvog svjetskog rata te ratnu povijest općenito. Bio je i urednik monumentalne The Encyclopedia of War u 5 tomova, koju je 2012. objavio poznati američki izdavač obrazovne literature Wiley. https://www.researchgate.net/profile/Gordon_Martel2/info. https://www.encyclopedia.com/arts/educational-magazines/martel-gordon https://www.wiley.com/en-gb/The+Encyclopedia+ of+War\%2C+5+Volume+Set-p- 9781405190374, posjećeno 6.62020. 
odbranu“ koja je „pod maskom kulturnog, gimnastičkog, streljačkog i sportskog društva ciljala potkopati lojalnost Srba austrijskom režimu"u Bosni i Hercegovini. Martel važnim smatra i zamisli Franje Ferdinanda o federalističkom, odnosno trijalističkom preuređenju Austro-Ugarske, što je srpskim nacionalistima izgledalo kao pokušaj sprječavanja ujedinjenja svih Srba i Jugoslavena oko Srbije zbog čega su Dragutin Dimitrijević Apis i njegova desna ruka Vojin Tankosić Franju Ferdinanda smatrali svojim najvećim neprijateljem. ${ }^{116}$

Nasuprot Martelu, već spomenuti britanski povjesničar John C. G. Röhl, ${ }^{117}$ u svojoj voluminoznoj knjizi Wilhelm II in to the Abyss of War nad Exile 19001941 izdanoj 2014., polazi sa stajališta da je službeni Berlin planirao izazivanje globalnog europskog sukoba. Zato on Sarajevski atentat i napete odnose između Austro-Ugarske i Srbije koji su uslijedili prikazuje kao kulisu iza koje je njemački vojni i politički vrh pripremao izazivanje rata, pri čemu Srbiju spominje samo u kontekstuželje službenog Beča da se obračunas, kako je to u svom pismu Wilhelmu II. naveo car Franjo Josip, „ruskom i srpskom propagandom ali i zavjerom čiji su konci vodili do Beograda i kojoj je cilj bio okupljanje svih južnih Slavena pod srpskom zastavom", a sve na račun Austro-Ugarske. Zato je Njemačka poznatim „bjanko-čekom“od 5. srpnja 1914. ohrabrila Austro-Ugarsku na brzu vojnu akciju protiv Srbije, a sve kako bi se iznenadnom akcijom izbjeglo miješanje Rusije. Kad je postalo jasno da miješanje Rusije nije moguće izbjeći, njemački car pokazao je spremnost za popuštanje, posebno kad je postalo jasno da u slučaju europskog rata ne može računati na neutralnost Velike Britanije. Osim toga, 28. srpnja 1914. dobio je beogradski odgovor na austrougarski ultimatum koji je u svojim marginalijama ocijenio kao diplomatski „briljantno dostignuće“ beogradske vlade, koje predstavlja „veliku moralnu pobjedu za Beč“ is kojom „nestaje svaki razlog za rat", 118 što je, kako se poslije pokazalo, bila pogrešna procjena.

Skidajući s dnevnog reda odgovornosti Srbije, Röhl je 2015. u svom članku u časopisu Inernatinal Affairs, koji se može smatrati pokušajem oživljavanja spomenute „Fischerove kontroverze“, ustvrdio da spomenuti „revizionist“ Christopher Clark oslobađa Njemačku odgovornosti „svaljujući u velikoj mjeri krivnju na malenu Srbiju zatim na Rusiju, Francusku i Britaniju, nudeći sliku Austro-Ugarske koja čini sve kako bi izbjegla rat; u potpunosti zaobilazeći dokaze

116 Gordon Martel, The Month that changed the World, July 1914., Oxford, 2014., 58, 74, 96, 97, 207, 208.

117 John C. G. Röhl. je profesor emeritus povijesti na Sveučilištu Sussex. Poznat je po studioznom istraživanju vladavine njemačkog cara Wilelma II. koje je rezultiralo brojnim i nagrađivanim knjigama. https://www.ias.edu/scholars/john-c-g-r\%C3\%B6hl. https://www.bitebackpublishing. com/authors/john-c-g-rohl, posjećeno 5. 6. 2020.

118 John C. G. RöHL, Wilhelm II in to the Abyss of War nad Exile 1900.-1941, Cambridge, 2014., 1023 1025, 1030, 1031, 1037, 1046, 1051, 1052, 1054. 
o namjeri Njemačke da izazove rat“. Iz njegove perspektive to je revizionizam koji odbacuje teze Fritza Fischera, a sve kako bi Nijemci, slično kao Francuzi i Britanci, mogli stvoriti „nacionalni mit oslobođen krivnje“.119

Na koncu, valja spomenuti da irski povjesničar John Paul Newman, ${ }^{120}$ sasvim suprotno od Röhla, u svom znanstvenom članku iz 2015. suodgovornost Srbije sagledava kroz „institucionalni ekstremizam srbijanske vojske koji nije podnosio prepreke“, što se najbolje vidjelo u svibnju 1914. kada se spremao državni udar protiv onih koji su „indiferentni ili protivni nacionalnim ciljevima“. Ova je „militaristička klika“ kroz četnički pokret i beogradsku obavještajnu mrežu, koristeći mlade srpske imigrante iz Bosne i Hercegovine, namjeravala osvojiti habsburške teritorije na kojima su živjeli Srbi, što je bilo protivno tadašnjim ciljevima beogradske vlade koja je nakon pobjeda u Balkanskim ratovima htjela stanku u revolucionarnim aktivnostima. Ovakva unutrašnja podijeljenost, „uskoro je gurnula zemlju u puno opasniji i skuplji rat“, što će reći u sukob s Austro-Ugarskom koji je vrlo brzo prerastao u svjetski rat. U pozadini svega Newman vidi „mrtvački lubanju“, odnosno trag smrti koji smatra ključnim za razumijevanje prirode srpske države u razdoblju od krvavog beogradskog prevrata 1903. do Sarajevskog atentata i izbijanja prvog svjetskog rata $1914 .^{121}$

\section{ZAKLJUČAK}

Uloga Kraljevine Srbije u Sarajevskom atentatu i izbijanju Prvog svjetskog rata predmet je historiografskih, memoarskih i drugih kontroverzi koje traju već više od jednog stoljeća. Na osnovu teze koju je 2005. postavio utjecajni američkofrancuski povjesničarski dvojac Jay Winter i Antonie Prost kako „sve države, svi narodi, u različitoj mjeri dijele odgovornost za katastrofu koju nisu bili u stanju predvidjeti i spriječiti“ “122 ovdje je donesen opširan kronološki pregled relevantnih naslova objavljenih u razdoblju od 1915. do 2015., a koji su se bavili kontroverznim pitanjem suodgovornosti Kraljevine Srbije za izbijanje Prvog svjetskog rata.

119 J. C. G. RöHL, Goodbye to all that (again)?, The Fischer thesis, the new revisionism and the meaning of the First World War, International Affairs, 91: 1 (2015.), 154, 159, 166.

120 Dr. John Paul Newman, profesor povijesti XX. stoljeća na Sveučilištu Maynoth u Irskoj. Za temu o kojoj je ovdje riječ zanimljivo je spomenuti da Newman trenutno istražuje onodobno paramilitarno nasilje na Balkanu. https://www.maynoothuniversity.ie/europe/our-people/johnpaul-newman\#3, posjećeno 5. 6. 2020.

121 John Paul Newman, Civil and Military relations in Serbia during 1903-1914, u: The Wars before Great War, ur. Dominik Geppert, William Mulligan, Andreas Rose, Cambridge, 2015., 116, 17, 114 $-128$.

122 J. Winter, A. Prost, The Great War in History, 13, 156, 204. 
Različita i nerijetko oprečna stajališta pokazuju da je ova kontroverza vrlo realan i zanimljiv povijesni problem koji se ne može svesti na upiranje prstom u službeni Beograd, odnosno na negiranje njegove odgovornosti.U tom je smislu npr. način na koji je 1915., na osnovi vrlo ograničenog izvornog materijala i osobnih preduvjerenja, američki politolog John William Burgess Kraljevini Srbiji pripisao veliki dio krivnje za rat danas zastario. Isto kao i stajalište i francuskog ekonomista Yvesa Gyota koji, iako Sarajevski atentat smatra zločinom, u njegovoj pozadini vidi otpor agresivnim namjerama Austro-Ugarske koja je, zbog straha od jačanja pokreta srpsko-hrvatskog jedinstva na svom teritoriju, htjela uništiti Srbiju, u čemu je imala potporu militarističke Njemačke. ${ }^{123}$ Ipak, i danas je relevantno stajalište koje je još 1930. iznio američki „revizionistički“ povjesničar H. E. Barnes da je „sigurno da su srpski zavjerenici planirali ubojstvo nadvojvode učiniti sredstvom strmoglavljivanja Europe u rat, dok su austrijski vojni i civilni dužnosnici bili odlučni isto djelo upotrijebiti za dugo odgađano kažnjavanje Srbije. Pitanje je samo koji je od ovih planova bio nečasniji i opasniji."124

Zanimljivo je i stajalište suvremenog beogradskog povjesničara Mile Bjelajca koji je 2014. postavio pitanje: „Kako to da je za Europu najopasniji bio mali srpski nacionalizam i imperijalizam?" ${ }^{25}$

Ova, kao i brojna druga ovdje iznesena gledišta koristan su uvod i poticaj za daljnje istraživanje kontroverze o kompleksnoj pozadini suodgovornosti Kraljevine Srbije za Prvi svjetski rat. Osim navedene literature tu suodgovornost razotkrivaju brojni povijesni izvori, na prvom mjestu Dokumenti o spoljnjoj politici Kraljevine Srbije, koji su objavljeni u razdoblju od 1980. do 2015. i koji donose podatke o višedijelnoj beogradskoj obavještajnoj i revolucionarnoterorističkoj mreži koja je djelovala pod okriljem beogradske vlade ili uz njezino znanje. Uvid u ove, ali i druge izvore, na kojima će se temeljiti monografija koju trenutno pišem, omogućit će puno jasniji i detaljniji odgovor na pitanje o razini suodgovornosti Kraljevine Srbije.

Stogodišnja, internacionalna rasprava o toj suodgovornosti u Hrvatskoj je manje-više nepoznata pa je ovaj članak zamišljen kao poticaj za daljnje istraživanje ovog problema koji je, kroz ideologiju i politiku jugoslavenstva, u znatnoj mjeri obilježio sudbinu Hrvatske u XX. stoljeću.

123 Yves Guyot, Causes and Cosenquences of the War, London, 1916., X, 3, 7, $18-20,270-272$. Francuski izvornik objavljen je u Parizu 1915. pod naslovom Les Causes et les Consénqences de la Guerre.

124 H. E. Barnes, The Genesis of the World War, 173, 174.

125 M. BJelajac, 1914-2014: Zašto revizija?, 7. 


\section{IZVORI I LITERATURA}

\section{OBJAVLJENI IZVORI:}

Albertini, Luigi, The Origins of the War of 1914., volume II., Westport, Connecticut 1980, Reprint.

ApPonYi, Albert, Austria-Hungary and War, New York, 1915.

Boghitcévitch, Miloš, Causes of the War, Amsterdam-Rotterdam 1919.

ČErović, Božo, Bosanska omladina i Sarajevski atentat, Sarajevo, 1930.

LiCHnows Ky, Prince, My Mission to London, New York, 1918.

Lich Nows Ky, Prince, Heading for the Abyss. Reminiscences, New York, 1928.

Sazonov, Serge, Fateful Years, London, 1928.

\section{LITERATURA:}

BARnes, Harry E., The Genesis of the World War, London-New York, 1927.

BAtaković, Dušan T., The Salonica trial 1917. Black Hand vs Democrarcy, u:

The Salonica Theatre of operation and the outcome of Great War, Institute for Balkan studies 277 (2005), 273 - 293.

Bataković, Dušan T., Storm over Serbia. The Rivalry between Civil and Military authorities (1911.-1914.), Balcanica, 54/2013., 307 - 356.

Bataković, Dušan T., Prelude to Sarajevo. The Serbian Question in Bosnia and Herzegovina 1878.-1914., Balcanica XXVII, 1996., 117 - 155.

BELIĆ, Milorad, Komitski vojvoda Vojislav Tankosić, Valjevo, 2005.

Bjelajac, Mile, Novi (stari) zapleti oko uzroka Prvog svetskog rata pred obeležavanje 100. godišnjice, Tokovi istorije, svezaka br. 1, 2013., 15 - 62.

BjelajAC, Mile, 1914-2014: Zašto revizija?, Beograd, 2014.

Burgess, John William, The European War of 1914. It's causes, purposes, and probable results, Chicago, 1915.

Buxton, Noel, Buxton, Charles R., The War and The Balkans, London, 1915.

Clark, Christopher, The Sleepwalkers. How Europe Went to War in 1914., London, 2012.

DEDIJER, Vladimir, Sarajevo 1914, knjiga II., Beograd, 1978.

Doenecke, Justus E., Harry Elmer Barnes, The Wisconsin Magazine of History, Vol. 56, No. 4, Summer, 1973., 311 - 323.

Draš ković, Radovan M., Pretorijanske težnje u Srbiji, Beograd, 2006.

FAY, Sidney Bradshaw, The Origins of the World War, volume II, New York, 1928. FISCHER, Fritz, Germany's war aims in the First World War, New York, 1967. 
Fischer, Fritz, War of illusions, German Policies from 1911 to 1914., New York, 1975.

FRIED, Marvin Benjamin, Austro-Hungarian War Aims in the Balkans during World War I, London, 2014.

Fromkin, David, Europe's Last Summer. Who started Great War in 1914, New York, 2004.

Guyot, Yves, Causes and Cosenquences of the War, London, 1916.

Hall, Richard C., Serbia, u: The Origins of World War I, ur. Richard F. Hamilton, Holger H. Helwig, Cambridge, New York, 2003., 92 - 111.

Jelavich, Barbara, History of the Balkans. Twentieth Century, volume 2, Cambridge, New York, 1983.

JELAVICH, Barbara, Russia's Balkan entanglments 1806-1914, Cambridge, 1991.

JoLl, James, The Origins of the First World War, London, 1984.

Joll, James, Gordon Martel, The Origins of the First World War, 3rd edition, New York, 2007.

Kazimirović, Vasa, Crna ruka, Kragujevac, 1997.

KeIger, John F. V., France and the Origins of the First World War, London, 1983.

LEVy, Jack. S., Preferences, Constraints and Choices in July 1914, International Security, vol 15., No. 3, 1990., 151 - 186.

Ljubibratić, Drago, Gavrilo Princip, Beograd, 1959.

LjubibRatić, Drago, Vladimir Gaćinović, Beograd, 1961.

MacKenzie, David, Apis: Congenial Conspirator, New York, 1989.

MacMillan, Margareth, War that ended the peace, London, 2013.

MArtel, Gordon, The Month that changed the World, July 1914., Oxford, 2014.

McMeEkin, Sean, The Russian Origins of the First World War, Cambridge, 2011.

McMeekin, Sean, July 1914. Countdown to War, London, 2014.

Mitrović, Andrej, Prodor na Balkan, Beograd, 1981.

Mitrović, Andrej, Srbija u prvom svetskom ratu, drugo izdanje, Beograd, 2015.

Mombauer, Anika, The Origins of the First world War, London, 2002.

Newman, John Paul, Civil and Military relations in Serbia during 1903-1914, u

The Wars before Great War, ur. Dominik Geppert, William Mulligan, Andreas Rose, Cambridge, 2015., 114 - 128.

OKey, Robin, Taming Balkan nationalism, New York, 2007.

Perović, Latinka, Historian Đorđe Stanković, Prof. PhD (1944-2017), Tokovi istorije, 3/2018., 147 - 169.

Popović-ObRadović, Olga, The Parliamentary system in Serbia 1903-1914, Beograd, 2013.

Pribram, Alfred Francis, Austrian foreign policy, 1908-1918, London, 1923. 
RAJČıć, Tihomir, „Mac Milan: Crna ruka je bila kao Al-Qa’da. Bataković: Nije istina Srbija je bila uzorna“, Slobodna Dalmacija, 30. lipnja 2014., https:// slobodnadalmacija.hr/vijesti/svijet/macmillan-crna-ruka-je-kao-al-qa-idabatakovic-nije-istina-srbija-je-bila-uzorna-238534, posjećeno 23. 6. 2020.

RaJČıć, Tihomir, Gdje je udarala Crna ruka? U toj četničkoj organizaciji bilo je i uglednih Splićana“, Slobodna Dalmacija, 15. veljače 2017. https:// slobodnadalmacija.hr/vijesti/hrvatska/gdje-je-udarala-crna-ruka-u-tojcetnickoj-organizaciji-bilo-je-i-uglednih-splicana-468548, posjećeno 23. 6 . 2020.

Rajčıć, Tihomir, Problem uloge Kraljevine Srbije u Sarajevskom atentatu i izbijanju Prvog svjetskog rata, Radovi Zavoda za povijesne znanosti HAZU u Zadru (59/2017)., 407 - 434.

RAJČıć, Tihomir, Atentat na Franju Ferdinanda dio je projekta Velike Srbije, Slobodna Dalmacija, 30. lipnja 2018.

RAJČIć, Tihomir, Beogradski plan: Kad propadne Austrija, nastat će Velika Srbija, Slobodna Dalmacija, 6. srpnja 2019.

RajČIĆ, Tihomir, Ferdinanda je u smrt odveo njegov general, Slobodna Dalmacija, 28. lipnja 2020.

Rauchensteiner, Manfried, The First World War and the end of the Habsburg Monarchy, Wien-Köln-Weimar, 2014.

Rema K, Joachim, Sarajevo. Story of Political Murder, New York, 1959.

Remak, Joachim, The Third Balkan War. Origins reconsidered, The Journal of Modern History, vol. 43., no. 3, 1971., 353 - 366.

RöHL, John C. G., Wilhelm II in to the Abyss of War nad Exile 1900-1941, Cambridge, 2014.

RöHL, J. C. G., Goodbye to all that (again)?, The Fischer thesis, the new revisionism and the meaning of the First World War, International Affairs, 91: 1 (2015)., 153 - 166.

Schmitt, Bernadotte E., The Coming of the War 1914, volume I, New YorkLondon, 1930.

Seaton-Watson, Robert W., Sarajevo. A study in the origins of the Great War, London, 1925.

Sontag, Raymond J., European Diplomatic History 1871- 1932, New York, 1933.

Stanković, Đorđe Đ., Nikola Pašić, saveznici i stvaranje Jugoslavije, Beograd, 1984.

Stanković, Đorđe Đ., Nikola Pašić i jugoslovensko pitanje, sv. 1, Beograd, 1985.

Strachan, Hew, The First World War, volume I, New York, 2001. 
Williamson jr., Samuel R., Austria-Hungary and Origins of the First World War, New York, 1991.

Williamson, Jr., Samuel R., The Origins of World War I, Journal of Interdisciplinary History, XVII, 4/1988., 795 - 818.

Williamson Jr., Samuel R., May, Ernst R., An Identity of Opinion: Historians and July 1914., The Journal of Modern History, vol 79, no. 2 / 2007., 335 - 387. Winter, Jay, Prost, Antonie, The Great War in History, Cambridge, 2005.

ZAGARE, Frank C., Explaning the 1914 War in Europe, Journal of Theoretical Politics, 21 (1) 2009., 63 - 95.

Zagare, Frank C., After Sarajevo: Explaining the Blank Check, International Interactions, 35/ 2009., 106 - 127.

Zagare, Frank C., The Games of July, Ann Arbor, 2011. 
Tihomir RAJČIĆ

CENTENNIAL CONTROVERSY ON SERBIA'S JOINT RESPONSIBILITY FOR THE SARAJEVO ASSASSINATION AND THE FIRST WORLD WAR

(1915-2015)

\section{SUMMARY}

This article deals with historiographical controversies about the role played by the Kingdom of Serbia in the Sarajevo assassination and the outbreak of the First World War, which has been in focus for more than a century. A thesis was put forward in 2005 by the influential American-French duo of historians JayWinter and Antonie Pros that, after the fall of the Berlin Wall in 1989 and the Maastricht Treaty in 1992, World War I increasingly began to look like a "European civil war." For this reason, all states, all nations, share to a different extent the responsibility for a catastrophe they were unable to predict and prevent "Starting from this thesis, the author provides an extensive chronological overview of the findings from 65 historiographical, memoir political science titles published in the period from 1915 to 2015.

The overview is divided into three, chronologically arranged, chapters.

The first chapter, entitled "Debates on the Culpability of Serbia (1915-1961)", provides an overview of the debates about the guilt, i.e. coresponsibility, of the Kingdom of Serbia in the period from the polemical writing of the American political scientist from Columbia University John William Burgess from 1915 to the so-called "Fischer Controversies" from the 1960s.

The second chapter "New Knowledge in the Shadow of the Fischer Controversy (1961-2000)" provides an overview of the insights from the influential 1961 book by the famous German historian Fritz Fischer, Griffnachder Weltmacht. The book sparked a debate on the liability of Germany for World War I outbreak, and it has lasted to the early 21st century when the focus shifted again to the Balkans.

That is why the third chapter "Return to the Balkans (2001-2015)" gives an overview of the latest discussions, which are primarily focused on different views and arguments about Serbia's co-responsibility for the Sarajevo assassination and the First World War.

In conclusion, the author summarises a whole range of, often quite contradictory, views that represent an indispensable introduction and impetus for further research into the controversy over the co-responsibility of the 
Kingdom of Serbia for the Sarajevo assassination and the First World War. And the author believes that the discussion of the complex backdrop cannot only come down to pointing the finger at official Belgrade or denying its joint responsibility.

Keywords: co-responsibility of Serbia, historiographical controversy, World War I. 